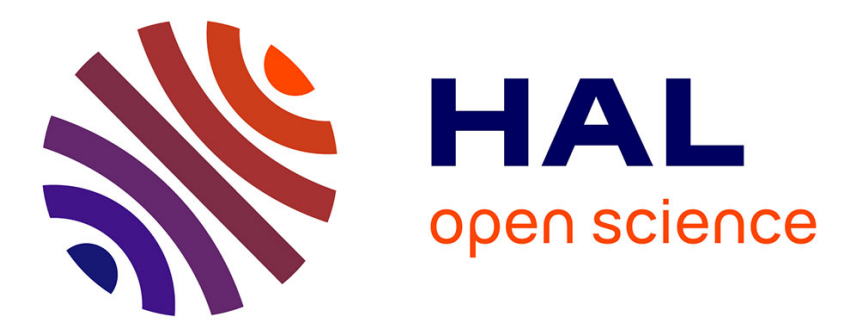

\title{
Development of chiral phosphoric acids based on ferrocene-bridged paracyclophane frameworks
}

Jérémy Stemper, Kevin Isaac, Julien Pastor, Gilles Frison, Pascal Retailleau, Arnaud Voituriez, Jean-François Betzer, Angela Marinetti

\section{- To cite this version:}

Jérémy Stemper, Kevin Isaac, Julien Pastor, Gilles Frison, Pascal Retailleau, et al.. Development of chiral phosphoric acids based on ferrocene-bridged paracyclophane frameworks. Advanced Synthesis and Catalysis, 2013, 355, pp.3613-3624. 10.1002/adsc.201300697 . hal-00872550

\section{HAL Id: hal-00872550 \\ https://hal.science/hal-00872550}

Submitted on 14 Oct 2013

HAL is a multi-disciplinary open access archive for the deposit and dissemination of scientific research documents, whether they are published or not. The documents may come from teaching and research institutions in France or abroad, or from public or private research centers.
L'archive ouverte pluridisciplinaire HAL, est destinée au dépôt et à la diffusion de documents scientifiques de niveau recherche, publiés ou non, émanant des établissements d'enseignement et de recherche français ou étrangers, des laboratoires publics ou privés. 


\section{FULL PAPER}

Development of chiral phosphoric acids based on ferrocene-bridged paracyclophane frameworks

Adv. Synth. Catal. Year, Volume, Page - Page

Jérémy Stemper, Kévin Isaac, Julien Pastor, Gilles
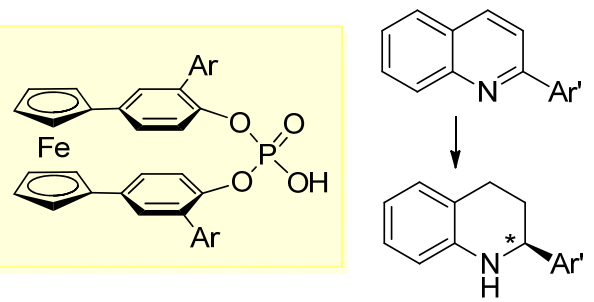

Frison, Pascal Retailleau, Arnaud Voituriez, Jean-

François Betzer* and Angela Marinetti*

up to $92 \%$ ee 


\title{
Development of chiral phosphoric acids based on ferrocene-bridged paracyclophane frameworks
}

\author{
Jérémy Stemper, ${ }^{\mathrm{a}}$ Kévin Isaac, ${ }^{\mathrm{a}}$ Julien Pastor, ${ }^{\mathrm{b}}$ Gilles Frison, ${ }^{\mathrm{b}}$ Pascal Retailleau, ${ }^{\mathrm{a}}$ \\ Arnaud Voituriez, ${ }^{\mathrm{a}}$ Jean-François Betzer*a and Angela Marinetti*a \\ a Institut de Chimie des Substances Naturelles, CNRS UPR 2301, Centre de Recherche de Gif, 91198 Gif-sur-Yvette, \\ France \\ Fax+33(1)69077247; e-mail: jean-francois.betzer@cnrs.fr; angela.marinetti@cnrs.fr \\ b Laboratoire des Mécanismes Réactionnels, Department of Chemistry, Ecole Polytechnique and CNRS, 91128 \\ Palaiseau, France
}

Received:

Supporting information for this article is available on the WWW under http://dx.doi.org/10.1002/adsc.201\#\#\#\#\#\#.

\begin{abstract}
This work deals with the development of a new family of planar chiral phosphoric acids, based on a ferrocenophane/paracyclophane scaffold. The synthetic approach has been improved by taking advantage of a chiral phosphorylating agent to access enantiomerically enriched acids via diastereomers separation.
\end{abstract}

\section{Introduction}

The use of chiral phosphoric acids in organocatalytic processes has experienced an exponential growth following to the seminal work of Terada $^{[1]}$ and Akiyama ${ }^{[2]}$ on enantioselective Mannich type reactions. Among the most classical applications, Biginelli, Pictet-Spengler, Friedel-Crafts, ene-type and Diels-Alder reactions can be mentioned. ${ }^{[3]}$ Moreover, several unprecedented uses have been reported recently which include the desymetrization of tetrasubstituted biaryls by asymmetric bromination, ${ }^{[4]}$, the oxyfluorination of enamides, ${ }^{[5]}$ the asymmetric protonation of ketene dithioacetals and silyl ketene imines ${ }^{[6]}$ and others. ${ }^{[7]}$ The privileged phosphoric acids for these applications are mainly issued from chiral BINOL, SPINOL ${ }^{[8]}$ VANOL and VAPOL $^{[9]}$ derivatives, i.e. from $\mathrm{C} 2$-symmetric axially chiral diols. Surprisingly, planar chirality has not been exploited so far for building phosphoric acids, although planar chiral structural units are known to afford efficient auxiliaries in other fields. ${ }^{[10]}$ In the case of phosphoric acids, it can be expected that planar chiral scaffolds would create completely different asymmetric environments, with respect to
These phosphoric acids have been used as catalysts for the enantioselective $\mathrm{H}$-transfer reduction of $\alpha$-substituted quinolines with Hantzsch esters. Optimization of both the catalyst and the Hantzsch reductant allowed ee in the range $82-92 \%$ to be attained starting from $\alpha$-arylquinolines.

Keywords: phosphoric acid; planar chirality; chiral phosphorodiamidites; paracyclophanes; organocatalysis.

\section{Results and Discussion}

At the start of our studies, our aim was to develop a new series of phosphoric acids, based on planar chiral paracyclophane scaffolds. As far as we know, the literature reports only one compound of this class, the Enders's acid A, in which a phosphoric acid function is embedded in the five-atom chain tethering 
an unsymmetric [2.2]paracyclophane unit. This Brønsted acid catalyst had been evaluated in Mannich type reactions affording moderate enantiomeric excesses (ee.s up to $38 \%$ ). ${ }^{12]}$

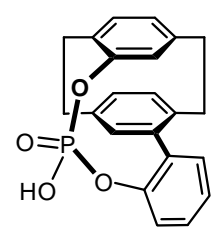

A

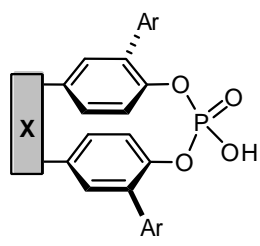

Figure 1. Enders planar chiral phosphoric acid (A) and targeted structures from this work (B)

Our target structures (B) differ from the Enders acid in as far as the O-P-O bridge itself would be a constitutive fragment of the C2-symmetric paracyclophane framework. In $\mathbf{B}$, planar chirality is generated by the two aryl substituents (Ar) on opposite edges of the paracyclophane. The only previous reports on related paracyclophanes and ferrocenophanes are due to Nifant' $\mathrm{ev}^{[13]}$ and Herberhold ${ }^{[14]}$ who synthesized racemic macrocyclic bis-phosphoramidites, and ferrocenic phosphonites and phosphates respectively. None of these compounds had been prepared in enantiomerically enriched form, neither they had been investigated for catalytic purposes.

As mentioned in our preliminary communication, ${ }^{[11]}$ phosphoric acids of the general formula $\mathbf{B}$ can be accessed when the tethering chain " $\mathrm{X}$ " is a 1,1 '-ferrocendiyl unit. This chain has been designed initially, following to calculations of the ring strain and configurational stability for a range of phosphoric acids of this class. Results of these calculations are reported hereafter in Scheme 1.

Two factors have been initially identified as crucial for the choice of the tethering chain. First, the strain energy associated with the macrocyclic structure: the longer the tethering chain " $X$ " is, the easier the cyclization process would be. Secondly, the configurational stability of the planar chiral scaffold: a long linker " $X$ " might induce loss of the configurational stability, by allowing easy rotation of the phenylene rings of the paracyclophane moiety around the $\mathrm{X}-\mathrm{C}_{\text {aryl }} \mathrm{O}$ axis. The nature of the tethering chain must therefore be finely adjusted. DFT calculations have been run to estimate ring strain energies for paracyclophanic acids, relative to the BINOL-derived phosphoric acid $\left(\Delta \mathrm{E}_{\mathrm{RSE}}\right)$, according to the isodesmic reaction depicted in Scheme 1. The computed data, obtained at the M06/6-31G(d,p) level are shown.

A 2-atoms chain (IIa) induces the larger ring strain energy, whereas 3-atom (IId) and, to a larger extend, 4-atom chains (IIf) significantly reduce strain. The 1,1 '-ferrocendiyl unit (IIe) decreases significantly the ring strain with respect to the 3 -atoms chains of IIb,c,d. This comparatively low ring strain likely relates to the high flexibility of the ferrocene unit, a unique structural feature that has allowed previously the synthesis of ferrocenophanes of various ring sizes, including the highly constraint phospha[1]- and phospha[2]ferrocenophanes. ${ }^{[15]}$
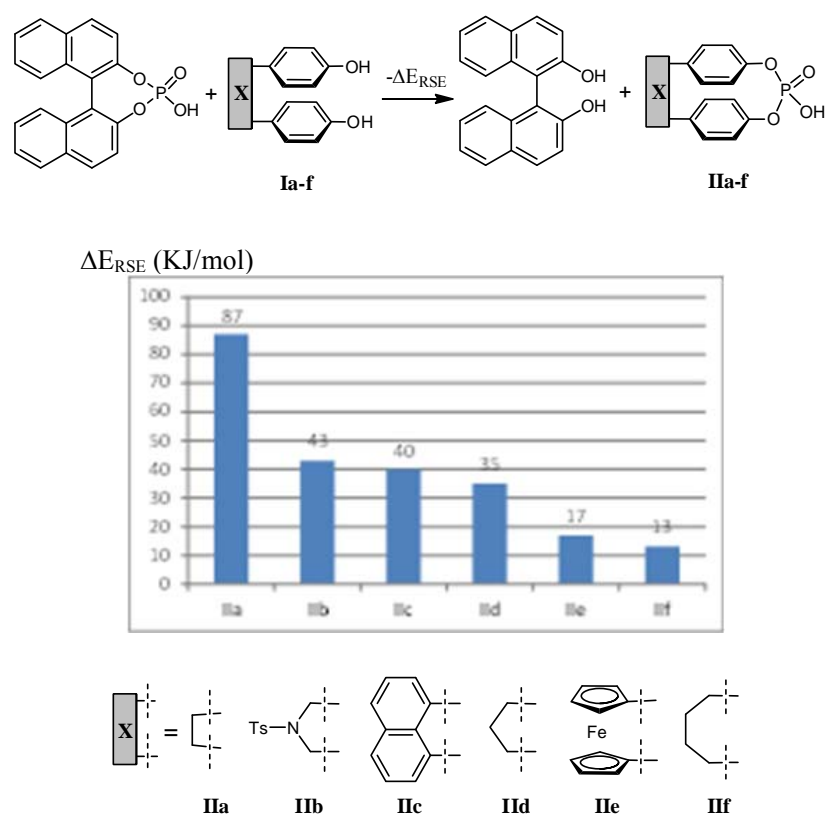

Scheme 1. Isodesmic reaction used to compute the relative ring strain energy of IIa-f relative to the BINOL-derived phosphoric acid.

Geometrical parameters of the macrocyclic structures IIa-f also correlate well with the computed ring strain energies: smaller and less flexible linkers increase the deformation angles of the benzene ring of the paracyclophane unit, ${ }^{[16]}$ as well as the strain of the O-P-O bridge, as shown by the increased $\mathrm{O} \cdots \mathrm{O}$ distance (see Table 3 in the experimental section).

Concerning the configurational stability of paracyclophanes, it has been computed recently that the barrier for rotation of the $p$-phenylene ring in [3.3] and [4.4]paracyclophanes are of about 300 and $80{\mathrm{~kJ} . \mathrm{mol}^{-1}}^{\text {, }}$ respectively, ${ }^{[17]}$ indicating that this barrier could be overcome only for the larger macrocycles and at high temperature. A similar trend is expected to be found in the targeted macrocyclic phosphoric acids. For the ferrocenic derivative IIe and the naphthalene derived macrocycle IIc, the energy barrier for the rotation of the $p$-phenylene units around the $\mathrm{X}-\mathrm{C}_{\mathrm{aryl}} \mathrm{O}$ axis have been calculated at about 216 and $387 \mathrm{~kJ} \mathrm{~mol}^{-1}$, respectively (at the M06/6-31G(d,p) level) in accordance with the chains size and flexibility of these structures.

The theoretical studies above have oriented our choice toward 1,1'-ferrocendiyl units as the key components of phosphoric acids $\mathbf{B}$, due to their low ring strain energy and high racemization barrier. Initial experiments have demonstrated that ferrocenebased paracyclophanes of the general formula $\mathbf{B}$ can be accessed indeed and display acceptable chemical and configurational stability. As described in our previous communication, the ferrocene tethered 
phosphoric acids 7 could be obtained according to two general strategies shown in Scheme 2. ${ }^{[11]}$

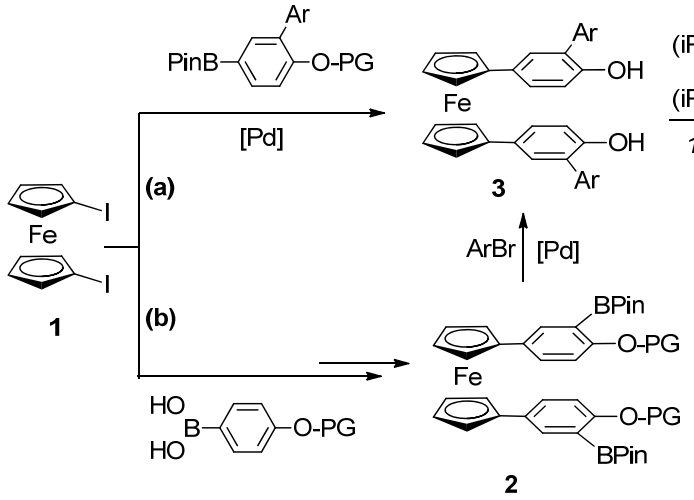

2

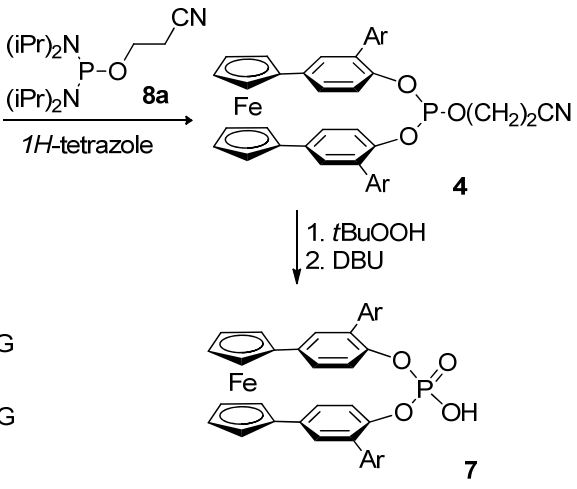

7a, $\mathrm{Ar}=\mathrm{Ph}$, pathway (a)

7b, Ar $=m$-terphenyl, pathway $(\mathrm{b})$

Scheme 2. Synthetic approaches to the 1,1'-ferrocendiyl tethered paracyclophanes 7

For both pathways, the key step is the macrocyclization reaction of a $1,1^{\prime}$-bis $(p$ hydroxyphenyl)ferrocene, 3 , with bis(diisopropylamino)cyanoethoxyphosphine 8a. The two pathways differ from each other by the reaction sequence leading to the ferrocenic diol 3. Pathway (a) involves the reaction of 1,1'-diiodoferrocene with a preformed biarylboronate in the presence of a palladium catalyst, under Suzuki conditions. Path (b) entails the synthesis of the bis-boronate 2 as a common platform allowing introduction of various aryl substituents (Ar) at a later step of the reaction sequence. The aryl substituents are introduced here by a palladium catalyzed Suzuki coupling on 2. In the final steps of the reaction sequence, diols 3 have been reacted with bis(diisopropylamino)cyanoethoxyphosphine in the presence of four equivalents of tetrazole to afford the desired $\mathrm{dl}$-phosphites $4 .^{[18]}$ Phosphites $\mathbf{4}$ have been oxidized into the corresponding phosphates with $t$ butylhydroperoxide, then removal of the cyanoethyl chain by elimination of acrylonitrile under basic conditions (DBU) afforded the racemic acids 7 . Pathway (a) has been applied to the synthesis of the phenyl-substituted phosphoric acid $7 \mathbf{a}(\mathrm{Ar}=\mathrm{Ph})$, while path (b) allowed the synthesis of the $m$ terphenyl substituted acid $\mathbf{7 b}$.

The racemic mixtures of $\mathbf{7 a}$ and $\mathbf{7 b}$ have been separated into enantiomerically pure acids by semipreparative HPLC on a CHIRALPAK ${ }^{\circledR}$ ID column.

The use of semi-preparative chiral HPLC as the resolution method is a potential drawback of the synthetic approach above, as far as it might prevent suitable scale-up of the acids 7. On the other hand, the strategy of resolving the diol precursors commonly applied to the synthesis of chiral phosphoric acids, ${ }^{[19]}$ can't be applied here because of the peculiar structural features of this series. Acids 7 differ indeed from the BINOL- or SPINOL-derived analogues on that chirality is generated at the phosphination step, while the diol precursors are achiral. This means that resolution must be performed at a later step of the synthetic sequence.

Thus, in order to avoid chiral HPLC separation, we have envisioned an original approach, i.e. the use of a chiral auxiliary as the phosphinating agent and subsequent separation of diastereomeric pairs. We have developed (S)-8b as a chiral variant of the classical cyanoethoxy-substituted phosphinating agent 8a. The new phosphorodiamidite (S)-8b contains a cyanoethoxy moiety as a precursor for the acidic P-OH function, but, unlike 8a, it displays a stereogenic carbon in close proximity to the phosphorus center. It is easily available in two steps, starting from the commercially available (R)-(-)-2chloro-1-phenylethanol, as shown in Scheme 3. After a $\mathrm{Cl} / \mathrm{CN}$ substitution step, the resulting (S)-3hydroxy-3-phenylpropanenitrile ${ }^{[20]}$ has been reacted with $\left(i \mathrm{Pr}_{2} \mathrm{~N}\right)_{2} \mathrm{PCl}$ at room temperature in the presence of $\mathrm{Et}_{3} \mathrm{~N}$. The desired phosphorodiamidite $(S)-\mathbf{8 b}$ has been isolated as a white solid after filtration on a silica gel column.

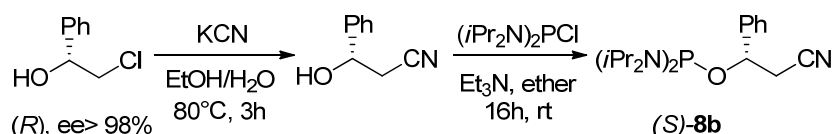
8b.

Phosphorodiamidite (S)-8b has been used as the phosphinating agent for the previously reported diols 3a $(\mathrm{Ar}=\mathrm{Ph})$ and $\mathbf{3 b}(\mathrm{Ar}=m$-terphenyl), but also for the newly synthesized ferrocenic diols $3 \mathbf{c}, \mathbf{d}(\mathrm{Ar}=p$ biphenyl and 3,5-( $\left.\left(\mathrm{CF}_{3}\right)_{2} \mathrm{C}_{6} \mathrm{H}_{3}\right)$, as shown in Scheme 4. Diol 3c has been prepared via palladium catalyzed coupling of 1,1'-diiodoferrocene, $\mathbf{1}$, with the corresponding biaryl-boronate (path (a) in Scheme 2). Diol 3d has been obtained via path (b) in Scheme 2, i.e. coupling of 1-bromo-3,5-bis(trifluoromethyl)- 
benzene with the ferrocenic bis-boronate $2(\mathrm{PG}=$ methoxymethyl, catalyst $\left.=\operatorname{Pd}\left(\mathrm{PPh}_{3}\right)_{4}\right)$. The experimental procedures for these reactions are given as Supporting Information.
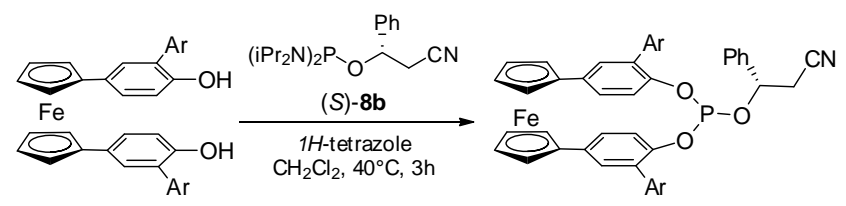

3a, $\mathrm{Ar}=\mathrm{Ph}$

3b, $\mathrm{Ar}=m$-terphenyl

3c, $\mathrm{Ar}=p$-biphenyl

3d, $\mathrm{Ar}=3,5-\left(\mathrm{CF}_{3}\right)_{2}-\mathrm{C}_{6} \mathrm{H}_{3}$

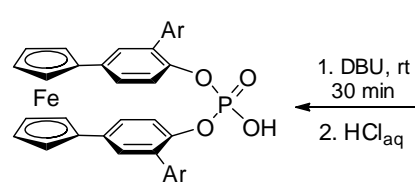

(R)/(S)-7a (95\%)

(R)/(S)-7b (67\%)

$(R) /(S)-7 \mathrm{c}(33 \%)$

$(R) /(S)-7 \mathrm{~d}(55 \%)$

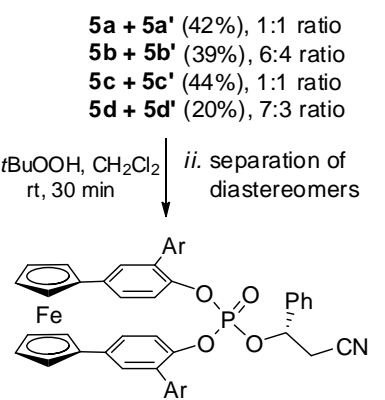

6a, 6a' (98\%)

6b, 6b' (77\%)

$6 c, 6 c^{\prime}(74 \%)$

6d, 6d' (65\%)

Scheme 4. Use of the chiral phosphorodiamidite (S)-8b in the synthesis of phosphoric acids 7 .

Diols 3a-d have been reacted with the chiral phosphorodiamidite $(S)-\mathbf{8 b}$ in the presence of $1 \mathrm{H}$ tetrazole to afford the desired macrocyclic, paracyclophane type phosphites 5a-d (Scheme 4). In principle, the cyclization step might afford both the meso and $d l$ isomers of $\mathbf{5}$, but, gratifyingly, these reactions occurred with high stereoselectivity leading to the desired $d l$ isomers as the only isolated products. We can assume that steric effects are responsible for the observed selectivity, as far as the steric hindrance of the Ar substituents is expected to favor their positioning on opposite faces of the paracyclophane ring. From these reactions, phosphites 5a-d have been isolated as mixtures of two epimers in $1: 1$ to $7: 3$ ratios. The mixtures have been oxidized with $t \mathrm{BuOOH}$ to obtain the corresponding phosphates 6ad. The four phosphates could be separated easily into pure diastereomers by either column chromatography (for 6b-d) or HPLC (for 6a). Thus, for instance, phosphates 6c,c' (Ar = 4-biphenyl) have been separated by flash chromatography on silica gel (Combiflash) with a toluene/heptane/THF gradient (from 60:30:0 to 60:30:2) as the eluent. 6c: $\mathrm{R}_{\mathrm{f}}=0.39$, $[\alpha]_{D}=+1151\left(\mathrm{c}=0.5, \mathrm{CHCl}_{3}\right) ; 6 \mathbf{c}^{\prime}: \mathrm{R}_{\mathrm{f}}=0.34,[\alpha]_{\mathrm{D}}=-$ $1138\left(\mathrm{c}=0.5, \mathrm{CHCl}_{3}\right) \quad$ (in toluene/heptane $/ \mathrm{THF}=$ $6: 3: 1)$.

An X-ray crystal study on 6c' demonstrated an (S)configuration of its planar chiral scaffold (Figure 2).

Since 6c' displays a negative rotatory power, we tentatively assume that, in the whole series, negative alpha-values are associated to phosphates and phosphoric acids with $(S)$-configurations.
The phosphates 6 are chemically and configurationally stable: neither decomposition nor interconversion of isomeric derivatives has been observed after either prolonged storage in air at room temperature or heating overnight at $80^{\circ} \mathrm{C}$.

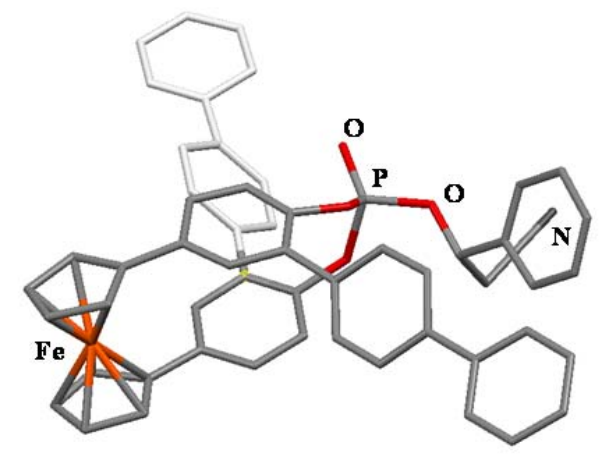

Figure 2. X-Ray crystal structure of $(-)-\left(S_{P}, S\right)-6 c^{\prime}$.

The last step of the reaction sequence in Scheme 4 is the removal of the chiral auxiliary. The 1-phenyl-2cyanoethyl chain could be removed under the conditions usually applied to removal of the analogous achiral cyanoethyl chain: DBU easily induces deprotonation and subsequent elimination of 3-phenylacrylonitrile, with concomitant generation of the desired phosphoric acid salt. Starting from single epimers of phosphates $\mathbf{6}$, the enantiomerically enriched acids 7a-d have been obtained as yelloworange solids after filtration on silica gel with a $\mathrm{DCM} / \mathrm{MeOH}$ gradient ( 0 to $10 \% \mathrm{MeOH}$ ) and workup with aqueous $\mathrm{HCl}(6 \mathrm{~N})$. The enantiomeric excesses of the acids have been measured by HPLC.

Unlike the corresponding phosphates $\mathbf{6}$, acids 7 displayed moderate thermal stability giving nonidentified decomposition products after heating at $60^{\circ} \mathrm{C}$ in toluene for several hours. For instance, 7a undergoes an estimated $10 \%$ decomposition after heating for $18 \mathrm{~h}$ at $60^{\circ} \mathrm{C}$. Therefore, to ensure the integrity of their molecular scaffold, these acids are stored routinely at $-20^{\circ} \mathrm{C}$ and used then in catalytic experiments at room temperature.

In summary, we have demonstrated here that the use of the chiral phosphorodiamidite $(S)-\mathbf{8 b}$ as the phosphinating agent provides an easier access to the phosphoric acids 7, the first family of planar chiral acids based on paracyclophane structures.

With suitable synthetic methods in hand, we have started then a systematic investigation of the behavior of acids $\mathbf{7}$ as Brønsted acid catalysts.

Our investigations have been focused on the transfer hydrogenation of 2-substituted quinolines with the Hantzsch ester as a benchmark reaction (Table 1). ${ }^{[21]}$ We have compared the catalytic properties of the four acids 7a-d which display aryl groups with various steric bulk and long-arm effects. The shape and bulk of these aryl substituents is 
expected to play a major role in enantioselective catalysis, as impressively demonstrated with the analogous BINOL-derived phosphoric acids. ${ }^{[22]}$

At first, the behavior of 7a-d has been surveyed in the reduction of 2-phenylquinoline with the Hantzsch ester 9a $(\mathrm{R}=\mathrm{Et}$, entries 1-4). All catalytic experiments have been run in toluene at a $0.05 \mathrm{mmol}$ scale. Standard conditions involve toluene as the solvent, room temperature, $10 \mathrm{~mol} \%$ of chiral catalyst.

Table 1. Survey of phosphoric acids and Hantzsch esters for the $\mathrm{H}$-transfer hydrogenation of 2-phenylquinoline

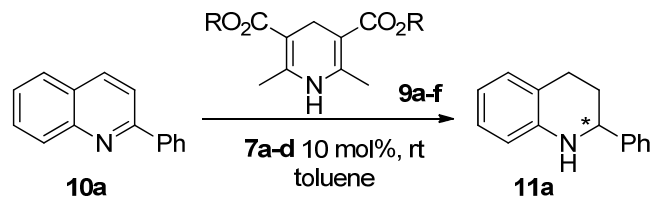

\begin{tabular}{|c|c|c|c|c|c|}
\hline & Catal. & Hant & h ester & $\begin{array}{l}\text { Time } \\
(\mathrm{h})^{[\mathrm{a}]}\end{array}$ & $\begin{array}{l}\text { Ee }{ }^{b}{ }^{b} \\
\text { (config) }\end{array}$ \\
\hline 1 & $(+)-7 \mathbf{a}$ & 9a & $\mathrm{Et}$ & 2 & $26(S)^{\mathrm{c})}$ \\
\hline 2 & $(+)-7 \mathbf{b}$ & 9a & $\mathrm{Et}$ & 2 & $60(S)$ \\
\hline 3 & $(+)-7 c$ & $9 a$ & Et & 2 & $55(S)^{\mathrm{d})}$ \\
\hline 4 & $(+)-7 d$ & 9a & Et & 2 & $56(S)$ \\
\hline 5 & $(-)-7 e$ & $9 a$ & Et & 2 & $26(R)^{\mathrm{f})}$ \\
\hline 6 & $(-)-7 \mathbf{b}$ & $9 b$ & $\mathrm{Me}$ & 16 & $50(R)$ \\
\hline 7 & $(-)-7 \mathbf{b}$ & 9c & $t-\mathrm{Bu}$ & $20^{\mathrm{e})}$ & $70(R)$ \\
\hline 8 & $(-)-7 \mathbf{b}$ & 9d & $\mathrm{CH}_{2} \mathrm{Ph}$ & 3 & $74(R)$ \\
\hline 9 & $(+)-7 \mathbf{b}$ & $9 \mathbf{e}$ & $\mathrm{CH}_{2}\left(4-\mathrm{MeO}-\mathrm{C}_{6} \mathrm{H}_{4}\right)$ & 2 & $85(S)$ \\
\hline 10 & $(-)-7 \mathbf{b}$ & 9f & $\mathrm{CH}_{2}\left(4-\mathrm{BnO}-\mathrm{C}_{6} \mathrm{H}_{4}\right)$ & 2 & $87(R)^{\mathrm{c})}$ \\
\hline
\end{tabular}

Reactions were run at a substrate concentration of 0.05 to $0.01 \mathrm{M}$, depending on the solubility of the Hantzsch ester in toluene. ${ }^{\text {a) }}$ Reaction times giving total conversion rates (NMR monitoring of the crude mixtures). b) Ee.s determined by HPLC on CHIRALPACK ${ }^{\circledR}$ IB (i-PrOH/ heptane 5:95). Configuration assigned from $[\alpha]_{D}$ values. ${ }^{[23]}$ c) The same conversion rate and ee were observed at a catalyst loading of $5 \mathrm{~mol} \%$. ${ }^{\text {d) }} \mathrm{CH}_{2} \mathrm{Cl}_{2}$ and THF were also used as solvents in this reaction, they afforded however lower reaction rates and enantioselectivity levels (ee = $30 \%$ ). ${ }^{\text {e) }} 80 \%$ conversion rate. ${ }^{\text {f) }} 5 \mathrm{~mol} \%$ catalyst.

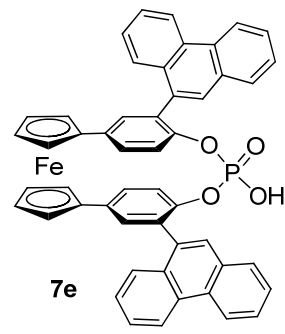

Acids 7a-d displayed excellent catalytic activity at room temperature, as they give total conversion in less than 2 hours. As anticipated, the nature of the aryl substituents of the acids strongly modulates the enantioselectivity levels, with enantiomeric excesses going from $26 \%$, for $\mathrm{Ar}=$ phenyl, to $60 \%$ for the bulky, $m$-terphenyl substituted acid.

In addition to catalysts $7 \mathbf{a}-\mathbf{d}$, we have tested also the 9-phenanthryl substituted acid 7e $\mathrm{e}^{[24]}$ (entry 5) since 9phenanthryl-substituents are known to give the most efficient acid in the binaphthyl series. ${ }^{[21 a]}$ Acid $7 \mathbf{e}$ afforded however a very low enantiomeric excess.
Generally speaking, the substituent effects do not follow the same trends in the binaphthyl-derived and paracyclophane type phosphoric acids. Such divergent substituent effects can be easily understood as far as the two series display totally different structural features and, especially, different arrangements of the aryl groups around the phosphorus functions. Comparative views of the molecular structures of the two phenyl-substituted acids obtained from DFT calculations are given in Figure 3 above.
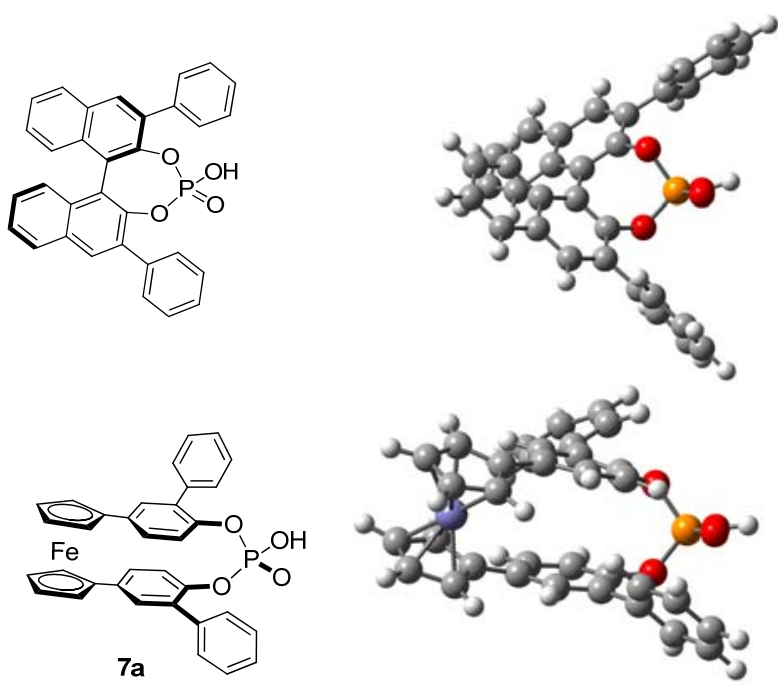

Figure 3. DFT computed molecular structures of a BINOL-derived phosphoric acid and the corresponding paracyclophanic acid 7a.

Most particularly, in 7a the eclipsed conformation of the ferrocene unit and the parallel arrangement of the $p$-phenylene groups cause a bent arrangement of the $\mathrm{O}-\mathrm{P}-\mathrm{O}$ function and subsequent loss of the $\mathrm{C} 2$ symmetry of the molecule. Therefore, while in the C2-symmetric BINOL-derived acid the phenyl groups are distributed symmetrically on opposite sides of the phosphorus function, in 7a one of the phenyl substituents becomes closer to the phosphorus function and the second one is kept away considerably. Based on these significant structural differences, we can't expect similar trends in the structure-activity relationships in the two series. This obviously prevents from making predictive hypotheses, but, on the other hand, the peculiar structural features of acids 7 might hopefully give complementary applications, with respect to BINOLderived acids and analogues.

From the initial screening of chiral acids in Table 1, entries $1-5$, we retained $\mathbf{7 b}(\mathrm{Ar}=$ terphenyl $)$ as the most promising catalyst for the $\mathrm{H}$-transfer reduction of 10a and we investigated then the role of the dihydropyridine partner (entries 2, 6-10 in Table 1). According to recent theoretical studies on the reduction of imines with Hantzsch esters, the esters are assumed to give H-bonds with the catalyst in the 
stereodetermining $\mathrm{H}$-transfer step. ${ }^{[25]}$ Consequently, the nature of the ester should have effects on the reaction outcome in terms of stereochemical control. Although so far literature shows that the Hantzsch ester plays a minor role in analogous reactions, ${ }^{[21 \mathrm{f}, 26]}$ in our study an extensive screening of esters has allowed a significant improvement of the enantioselectivity levels. Several known and new Hantzsch esters (e.g. $\mathrm{R}=t-\mathrm{Bu}, \mathrm{CH}_{2} \mathrm{Ph}, \mathrm{CH}_{2}$ (4$\left.\mathrm{MeOC}_{6} \mathrm{H}_{4}\right), \mathrm{CH}_{2}\left(4-\mathrm{BnO}-\mathrm{C}_{6} \mathrm{H}_{4}\right)$ ) have been prepared from formaldehyde, ammonium acetate and the desired acetoacetate, following an usual procedure. ${ }^{[27]}$

As shown in Table 1, in the reduction of 2phenylquinoline catalyzed by acid $\mathbf{7 b}$, the enantiomeric excess increased with the steric hindrance of the Hantzsch esters $(\mathrm{R}=\mathrm{Me}<\mathrm{Et}<\mathrm{tBu})$. Finally, benzyl esters afforded the highest enantioselectivity levels, with an $88 \%$ ee obtained with ester 9f, $\mathrm{R}=\mathrm{CH}_{2}\left(4-\mathrm{BnO}-\mathrm{C}_{6} \mathrm{H}_{4}\right)$. In these reactions, the catalyst loading could be decreased to 5 mol\% without decreasing the conversion rate and enantioselectivity.

With these improved conditions in hand ( $7 \mathbf{b}$ as the catalyst and 9f as the reducing agent) we have investigated the scope of the $\mathrm{H}$-transfer reaction by varying the quinoline substrates. The main results are summarized in Table 2.

Table 2. Survey of 2-substituted quinolines, 10, in $\mathrm{H}-$ transfer reductions promoted by $\mathbf{7 b}$.

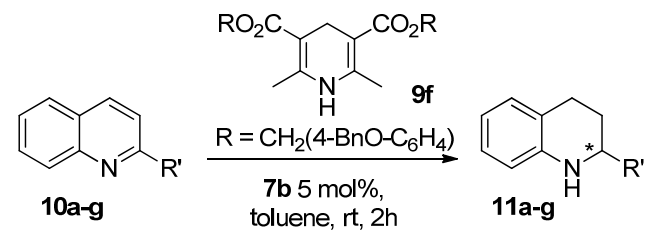

\begin{tabular}{|c|c|c|c|c|c|}
\hline \multicolumn{3}{|c|}{ Substrate } & Acid & Product $^{[\mathrm{a}]}$ & $\begin{array}{l}\text { Ee \% }^{[b]} \\
\text { (config.) }\end{array}$ \\
\hline 1 & $10 a$ & $\mathrm{Ph}$ & $(-)-7 \mathbf{b}$ & 11a & $87(R)$ \\
\hline 2 & 10b & 4-MeO- $\mathrm{C}_{6} \mathrm{H}_{4}$ & $(+)-7 \mathbf{b}$ & $11 b$ & $83(S)$ \\
\hline 3 & $10 c$ & 2-naphthyl & $(+)-7 \mathbf{b}$ & 11c & $92(S)$ \\
\hline 4 & 10d & p-biphenyl & $(-)-7 \mathbf{b}$ & 11d & $82(\mathrm{R})$ \\
\hline 5 & $10 \mathrm{e}$ & $3,5\left(\mathrm{CF}_{3}\right)_{2} \mathrm{C}_{6} \mathrm{H}_{3}$ & $(-)-7 \mathbf{b}$ & 11e & $87(+)$ \\
\hline 6 & $10 f$ & 1-naphthyl & $(-)-7 \mathbf{b}$ & $11 f^{[c]}$ & $40(R)$ \\
\hline 7 & $10 \mathrm{~g}$ & $\mathrm{C}_{6} \mathrm{H}_{11}$ & $(-)-7 \mathbf{b}$ & $11 \mathrm{~g}^{[\mathrm{c}]}$ & $40(R)$ \\
\hline
\end{tabular}

These experiments show that the new catalyst $7 \mathbf{b}$ affords high levels of enantioselectivity (ee 82-92\%) in the reduction of various $\alpha$-aryl substituted quinolines (entries 1-5). Under the same conditions, alkyl substituted quinolines are reduced with lower conversion rates and enantiomeric excess (entry 7: R' $=$ cyclohexyl, $40 \%$ ee). Even so, the potential of planar chiral paracyclophanic acids as enantioselective organocatalyst is demonstrated here.

\section{Conclusion}

This work has disclosed phosphoric acids 7 as the first series of enantiomerically enriched phosphoric acids with paracyclophane structures. Their unprecedented scaffolds display an O-P-O chain and a 1,1'-ferrocenediyl units tethering the aromatic rings of the paracyclophane, while suitably positioned aromatic substituents generate planar chirality. We have demonstrated that the planar chiral phosphoric acids $\mathbf{7}$ display high catalytic activity and promising enantioselectivity levels in model H-transfer reductions (ee.s up to 92\%). Their behavior as Brønsted acid organocatalysts will be further investigated. Given their peculiar structural features, including the lack of C2-symmetry, it can be anticipated that these acids will have complementary application fields with respect to other known chiral phosphoric acids. Further studies of their catalytic properties are ongoing in our group.

\section{Experimental Section}

\section{Computational method}

Calculations have been carried out with the Gaussian09 package of programs. ${ }^{[0]}$ Full geometry optimizations for all compounds were carried out with the use of the M06 $6^{[31]}$ density functional level of theory and the $6-31 \mathrm{G}(\mathrm{d}, \mathrm{p})$ basis set for all atoms. This level of calculation is known to produce reasonable geometries and energies for molecules in which non-covalent interactions, like $\pi-\pi$ interactions in paracyclophane-type systems, play a noticeable role. To get accurate geometries and energies, the SCF convergence criterion has been systematically tightened to $10^{-8}$ a.u., and the force minimizations were carried out until the rms force becomes smaller than (at least) $1 \times 10^{-5}$ a.u. Frequency analyses were carried out to confirm that the reported structures are minima or transition states on the M06/6-31G $(d, p)$ potential energy surface.

Table 3. Computed relative ring strain energy and geometric parameters for IIa-f.

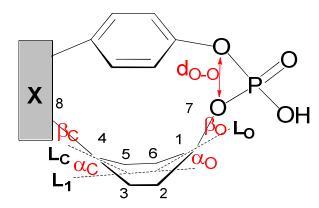

\begin{tabular}{lcccccc}
\hline & $\Delta \mathrm{E}_{\mathrm{RSE}}{ }^{\mathrm{b}}$ & $\alpha_{\mathrm{O}}{ }^{\mathrm{c}}$ & $\alpha_{\mathrm{C}}{ }^{\mathrm{c}}$ & $\beta_{\mathrm{O}}{ }^{\mathrm{c}}$ & $\beta_{\mathrm{C}}{ }^{\mathrm{c}}$ & $\mathrm{d}_{\mathrm{O}-\mathrm{O}}{ }^{\mathrm{d}}$ \\
\hline IIa & 87 & 11.1 & 10.0 & 2.6 & 11.8 & 2.611 \\
IIb & 43 & 7.8 & 6.2 & 2.1 & 6.3 & 2.596 \\
IIc & 40 & 9.5 & 8.2 & 2.5 & 0.9 & 2.601 \\
IId & 35 & 7.5 & 6.7 & 2.2 & 5.7 & 2.596 \\
IIe & 17 & 6.0 & 4.4 & 2.1 & 2.8 & 2.582 \\
IIf & 13 & 4.2 & 3.0 & 2.3 & 4.7 & 2.573
\end{tabular}

${ }^{a}$ Angle $\alpha_{O}\left(\alpha_{C}\right)$ is defined by lines $L_{1}$ and $L_{O}\left(L_{C}\right)$. Angle $\beta_{O}\left(\beta_{C}\right)$ is defined by line $\mathrm{L}_{\mathrm{O}}\left(\mathrm{L}_{\mathrm{C}}\right)$ and the $\mathrm{C}_{1}-\mathrm{O}_{7}\left(\mathrm{C}_{4}-\mathrm{C}_{8}\right)$ bond. $\mathrm{L}_{1}$ goes through the midpoints of $\mathrm{C}_{2}-\mathrm{C}_{6}$ and $\mathrm{C}_{3}-\mathrm{C}_{5}$. $\mathrm{L}_{\mathrm{O}}\left(\mathrm{L}_{\mathrm{C}}\right)$ goes through the midpoints of $\mathrm{C}_{2}-\mathrm{C}_{6}\left(\mathrm{C}_{3}-\mathrm{C}_{5}\right)$ and $\mathrm{C}_{1}\left(\mathrm{C}_{4}\right)$. ${ }^{\mathrm{a}}$ ring strain energy relative to the $\mathrm{BINOL}$-derived phosphoric acid in $\mathrm{kJ} / \mathrm{mol}$. phenylene ring deformation angles in degrees. ${ }^{\mathrm{c}} \mathrm{O} \cdots \mathrm{O}$ distance in $\AA$. $\mathrm{d}_{\mathrm{O}-\mathrm{O}}=2.536 \AA$ for the BINOL-derived phosphoric acid.

General. Semipreparative HPLC was carried out on a $\mathrm{SiO}_{2}$ column $(250 \times 10 \mathrm{~mm}, 5 \mathrm{mic}) .{ }^{31} \mathrm{P}$ NMR have been recorded at $202 \mathrm{MHz}$. Phosphoric acid (-)-7e (Ar = 9phenanthryl) has been prepared according to Scheme $2 b$. 
Quinolines 10b-f $\mathbf{f}^{[32]}$ and $\mathbf{1 0 g}^{[33]}$ have been prepared according to reported methods.

Synthesis of (S)-(2-cyano-1-phenylethyl) $N, N, N^{\prime}, N^{\prime}-$ tetra-isopropylphosphorodiamidite (S)-8b. (S)-2Cyano-1-phenylethanol ${ }^{[34]} \quad(3.90 \mathrm{~g}, 26.5 \mathrm{mmol})$ was dissolved in dry diethyl ether $(50 \mathrm{~mL})$, treated with anhydrous triethylamine $(4.06 \mathrm{~mL}, 29.2 \mathrm{mmol})$ and cooled to $0^{\circ} \mathrm{C}$. A solution of bis(diisopropylamino)chlorophosphine $(7.50 \mathrm{~g}, 26.5 \mathrm{mmol})$ in dry ether $(30 \mathrm{~mL})$ was added dropwise, the mixture was allowed to warm to room temperature and stirred overnight. The white solid was filtered off, the solution was evaporated under reduced pressure. The final product was purified by filtration on a short silica gel column with heptane/ethyl acetate/Et ${ }_{3} \mathrm{~N}$ 70:29:1 as the eluent to furnish $(\boldsymbol{S})-\mathbf{8 b}$ as a white solid. ${ }^{31} \mathrm{P}$ NMR $\left(\mathrm{CDCl}_{3}\right): \delta 114$ ppm. $\mathrm{H}$ NMR $\left(500 \mathrm{MHz}, \mathrm{CDCl}_{3}\right)$ : $7.41(\mathrm{~d}, J=7.8 \mathrm{~Hz}, 2 \mathrm{H}), 7.36(\mathrm{t}, J=7.8 \mathrm{~Hz}, 2 \mathrm{H}), 7.31(\mathrm{t}, J$ $=7.8 \mathrm{~Hz}, 1 \mathrm{H}), 4.85(\mathrm{dt}, J=11.4,6 \mathrm{~Hz}, 1 \mathrm{H}), 3.6(\mathrm{~m}, 2 \mathrm{H})$, $3.5(\mathrm{~m}, 2 \mathrm{H}), 2.85$ (ddd, $J=16.3,6.2 \mathrm{~Hz}, 1 \mathrm{H}), 2.78$ (dd, $J=$ $16.3,5.0 \mathrm{~Hz}, 1 \mathrm{H}), 1.27(\mathrm{~d}, J=6.8 \mathrm{~Hz}, 6 \mathrm{H}), 1.19(\mathrm{~d}, J=6.8$ $\mathrm{Hz}, 6 \mathrm{H}), 1.14(\mathrm{~d}, J=6.8 \mathrm{~Hz}, 6 \mathrm{H}), 1.03(\mathrm{~d}, J=6.8 \mathrm{~Hz}, 6 \mathrm{H})$. ${ }^{13} \mathrm{C}$ NMR $\left(75.5 \mathrm{MHz}, \mathrm{CDCl}_{3}\right): \delta 141.1(\mathrm{C}), 128.5(\mathrm{CH})$, $128.3(\mathrm{CH}), 126.2(\mathrm{CH}), 117.3(\mathrm{CN}), 71.3(\mathrm{~d}, J=18.6 \mathrm{~Hz}$, $\mathrm{CH}), 45.2(\mathrm{~d}, J=13.1 \mathrm{~Hz}, \mathrm{CH}), 44.8(\mathrm{~d}, J=13.1 \mathrm{~Hz}, \mathrm{CH})$, $28.6\left(\mathrm{~d}, J=4.4 \mathrm{~Hz}, \mathrm{CH}_{2}\right), 24.7\left(\mathrm{CH}_{3}\right), 24.6\left(\mathrm{CH}_{3}\right), 24.5$ $\left(\mathrm{CH}_{3}\right), 24.4\left(\mathrm{CH}_{3}\right), 24.3\left(\mathrm{CH}_{3}\right)$ ppm. HRMS (ESI) calcd. for $\mathrm{C}_{21} \mathrm{H}_{36} \mathrm{~N}_{32} \mathrm{OP} \quad\left[\mathrm{M}+\mathrm{H}_{2} \mathrm{O}+\mathrm{H}\right]:$ 396.2780, found 396.2809. $[\alpha]_{\mathrm{D}}=+37\left(c=1, \mathrm{CHC} l_{3}\right)$.

Representative procedures for the synthesis of the phosphoric acids 7:.Phosphoric acid 7a $(\mathrm{Ar}=\mathrm{Ph})$

(a) Phosphites 5a,a'. To a solution of 1,1'-bis-(4-hydroxy3-phenyl-1-phenyl)-ferrocene $3 a^{111}$ (261 mg, $0.50 \mathrm{mmol}$ ) and $1 H$-tetrazole $(147 \mathrm{mg}, 2.00 \mathrm{mmol}, 4$ eq.) in anhydrous DCM $(25 \mathrm{~mL})$ was added dropwise via cannula a solution of ((S)-2-cyanoethyl-1-phenyl)- $N, N, N^{\prime}, N^{\prime}$-tetraisopropylphosphorodiamidite $(S)-8 b(226 \mathrm{mg}, 0.60 \mathrm{mmol}, 1.2 \mathrm{eq}$.) in anhydrous DCM ( $5 \mathrm{~mL})$. The flask was then equipped with a reflux condenser and the mixture was heated at $40{ }^{\circ} \mathrm{C}$ for $3 \mathrm{~h}$. The reaction was then quenched by addition of saturated aqueous $\mathrm{NaHCO}_{3}(20 \mathrm{~mL})$ and extracted twice with DCM $(2 \times 20 \mathrm{~mL})$. The organic phase was dried over $\mathrm{MgSO}_{4}$ and the solvents were removed under reduced pressure. Purification by flash chromatography on silica gel (eluent: heptane/EtOAc 9:1) gave the desired macrocyclic phosphites 5a,a' (146 mg, 42\% yield) in a $1: 1$ ratio, as an orange solid. $R_{\mathrm{f}}=0.6$ (heptane/EtOAc 7:3). ${ }^{31} \mathrm{P}$ NMR $\left(\mathrm{CDCl}_{3}\right): \delta 131.2$ and $130.9 \mathrm{ppm} .{ }^{1} \mathrm{H}$ NMR $(500$ $\left.\mathrm{MHz}, \mathrm{CDCl}_{3}\right): \delta$ 7.60-7.25 (m, 14H), 7.14-7.08 (m, $\left.1 \mathrm{H}\right)$, 6.92-6.80 (m, 2H), 6.61-6.53 (m, 1H), 6.44-6.15 (m, 3H), 5.46-5.32 (m, 1H), 4.54 (bs, 1H), 4.50 (bs, 3H), 4.39 (bs, 2H), 4.35 (bs, 2H), 2.81-2.60 (m, 2H). HRMS (ESI) calcd. for $\mathrm{C}_{43} \mathrm{H}_{32} \mathrm{FeNO}_{3} \mathrm{P}[\mathrm{M}+\mathrm{H}]^{+}: 698.1547$, found : 698.1486 .

(b) Phosphates 6a, 6a'. A mixture of phosphites 5a,a' $(140 \mathrm{mg}, 0.20 \mathrm{mmol})$ was dissolved in DCM $(6 \mathrm{~mL})$. TBHP (5.5M in decane, $110 \mu \mathrm{L}, 0.60 \mathrm{mmol}$ ) was added to the solution at $0{ }^{\circ} \mathrm{C}$. Then the reaction mixture was allowed to warm to room temperature and stirred for 45 minutes. The reaction was treated with saturated aqueous $\mathrm{Na}_{2} \mathrm{~S}_{2} \mathrm{O}_{3}$. The layers were separated, the organic layer was dried over $\mathrm{MgSO}_{4}$ and concentrated in vacuo. The crude mixture was purified by chromatography on silica gel (heptane/EtOAc 7:3, $\mathrm{R}_{\mathrm{f}}=0.2$ ) to afford a mixture of $\mathbf{6 a}$,a' (140 mg, 98\% yield) as an orange solid. The mixture was separated by semi-preparative HPLC, with heptane./toluene/THF 35:70:5. Retention times: 6a, 21 min; 6a', 24 min.

6a: ${ }^{31} \mathrm{P}$ NMR $\left(\mathrm{CDCl}_{3}\right): \delta-15 \mathrm{ppm} .{ }^{1} \mathrm{H}$ NMR $(500 \mathrm{MHz}$, $\left.\mathrm{CDCl}_{3}\right): \delta 7.54(\mathrm{~m}, 2 \mathrm{H}), 7.5-7.4(\mathrm{~m}, 7 \mathrm{H}), 7.40(\mathrm{t}, J=7.3$ $\mathrm{Hz}, 1 \mathrm{H}), 7.3(\mathrm{~m}, 3 \mathrm{H}), 7.14(\mathrm{~m}, 2 \mathrm{H}), 6.98(\mathrm{bs}, 2 \mathrm{H}), 6.86(\mathrm{~d}$, $J=8.6 \mathrm{~Hz}, 1 \mathrm{H}), 6.34(\mathrm{dd}, J=8.6,2.3 \mathrm{~Hz}, 1 \mathrm{H}), 6.27(\mathrm{dd}, J$ $=8.3,2.3 \mathrm{~Hz}, 1 \mathrm{H}), 6.17(\mathrm{~d}, J=8.3 \mathrm{~Hz}, 1 \mathrm{H}), 5.32\left(\mathrm{dt}, J_{H-P}=\right.$ $6.9, J=6.2 \mathrm{~Hz}, 1 \mathrm{H}), 4.62(\mathrm{~s}, 1 \mathrm{H}), 4.59(\mathrm{~s}, 1 \mathrm{H}), 4.53(\mathrm{~s}$, $1 \mathrm{H}), 4.48(\mathrm{~s}, 1 \mathrm{H}), 4.40(\mathrm{~s}, 2 \mathrm{H}), 4.37(\mathrm{~s}, 2 \mathrm{H}), 2.83(\mathrm{~d}, J=$ $6.2 \mathrm{~Hz}, 2 \mathrm{H}) .{ }^{13} \mathrm{C}$ NMR $\left(75 \mathrm{MHz}, \mathrm{CDCl}_{3}\right): \delta 146.8(\mathrm{~d}, J=$ $6.4 \mathrm{~Hz}, \mathrm{C}), 145.9$ (d, J=8.6 Hz, C), 137.2 (C), 136.5 (C), 133.9 (C), 132.4 (d, J=7.5 Hz, C), 131.3 (C), 130.5 (C), $129.6(\mathrm{CH}), 129.2(\mathrm{CH}), 129.0(\mathrm{CH}), 128.9(\mathrm{CH}), 128.8$
$(\mathrm{CH}), 128.3(\mathrm{CH}), 128.1(\mathrm{CH}), 127.9(\mathrm{CH}), 127.2(\mathrm{CH})$, $126.2(\mathrm{CH}), 125.6(\mathrm{CH}), 122.4(\mathrm{CH}), 120.1(\mathrm{CH}), 115.5$ (CN), $85.8(\mathrm{C}), 76.6(\mathrm{~d}, J=6.6 \mathrm{~Hz}, \mathrm{CH}), 69.9(\mathrm{CH}), 69.8$ $(\mathrm{CH}), 69.3(\mathrm{CH}), 66.6(\mathrm{CH}), 66.5(\mathrm{CH}), 65.6(\mathrm{CH}), 65.4$ $(\mathrm{CH}), 27.6\left(\mathrm{~d}, J=8.8 \mathrm{~Hz}, \mathrm{CH}_{2}\right)$. IR: $v_{\max }=3031,3057$, $2961,2925,1732,1599,1574,1512,1495,1457,1412$ $1303,1261,1211,1055,1036,1022,930$. 'HRMS (ESI) calcd. for $\mathrm{C}_{43} \mathrm{H}_{33} \mathrm{FeNO}_{4} \mathrm{P} \quad[\mathrm{M}+\mathrm{H}]^{+}$: 714.1497, found: 714.1487. $[\alpha]_{\mathrm{D}}=+877\left(c=1, \mathrm{CHCl}_{3}\right)$.

6a': ${ }^{31} \mathbf{P}$ NMR $\left(\mathrm{CDCl}_{3}\right): \delta-15 \mathrm{ppm} .{ }^{\mathbf{1}} \mathbf{H}$ NMR $(300 \mathrm{MHz}$, $\left.\mathrm{CDCl}_{3}\right): \delta 7.6-7.3(\mathrm{~m}, 13 \mathrm{H}), 7.3-7.2(\mathrm{~m}, 3 \mathrm{H}), 6.99(\mathrm{bs}, 2 \mathrm{H})$, $6.62(\mathrm{~d}, J=8.5 \mathrm{~Hz}, 1 \mathrm{H}), 6.34(\mathrm{~d}, J=8.5 \mathrm{~Hz}, 1 \mathrm{H}), 6.26(\mathrm{dd}$, $J=8.5,1.5 \mathrm{~Hz}, 1 \mathrm{H}), 6.22(\mathrm{dd}, J=8.5,1.7 \mathrm{~Hz}, 1 \mathrm{H}), 5.50$ $(\mathrm{m}, 1 \mathrm{H}), 4.61$ (bs, 2H), 4.50 (bs, 2H), 4.40 (bs, 2H), 4.38 (bs, 2H), 2.67 (dd, $J=16.5,4.8 \mathrm{~Hz}, 1 \mathrm{H}), 2.46$ (dd, $J=16.5$, $7.4 \mathrm{~Hz}, 1 \mathrm{H}) .{ }^{13} \mathrm{C}$ NMR $\left(75.5 \mathrm{MHz}, \mathrm{CDCl}_{3}\right): \delta 146.6(\mathrm{C})$, 146.5 (C), 137.5 (C), 136.9 (C), 136.4 (C), 133.1 (C), 132.6 (C), 131.1 (C), 130.8 (C), $129.8(\mathrm{CH}), 129.5(\mathrm{CH})$, $129.3(\mathrm{CH}), 129.0(\mathrm{CH}), 128.8(\mathrm{CH}), 128.0(\mathrm{CH}), 127.7$ $(\mathrm{CH}), 126.4(\mathrm{CH}), 125.9(\mathrm{CH}), 125.4(\mathrm{CH}), 122.0(\mathrm{CH})$, $120.5(\mathrm{CH}), 115.6(\mathrm{CN}), 85.8(\mathrm{C}), 76.2(\mathrm{~d}, J=5.4 \mathrm{~Hz}, \mathrm{CH})$, $69.9(\mathrm{CH}), 69.3(\mathrm{CH}), 66.7(\mathrm{CH}), 66.6(\mathrm{CH}), 65.6(\mathrm{CH})$, $65.5(\mathrm{CH}), 26.7\left(\mathrm{~d}, J=6.5 \mathrm{~Hz}, \mathrm{CH}_{2}\right) . \quad \mathrm{IR}: v_{\max }=3056$, $3031,2926,2854,1732,1600,1574,1512,1495,1457$, $1412,1294,1262,1211,1129,1037,1014,973,936,822$ HRMS (ESI) calcd. for $\mathrm{C}_{43} \mathrm{H}_{33} \mathrm{FeNO}_{4} \mathrm{P}[\mathrm{M}+\mathrm{H}]^{+}: 714.1497$, found : 714.1498. $[\alpha]_{\mathrm{D}}=-871\left(c=1, \mathrm{CHCl}_{3}\right)$.

(c) Phosphoric acid (R)-7a. Phosphate $(R)-6 a(45 \mathrm{mg}$, $0.06 \mathrm{mmol})$ was dissolved in DCM $(2 \mathrm{~mL})$ and DBU (19 $\mu \mathrm{L}, 0.12 \mathrm{mmol}$ ) was added at rt. After $30 \mathrm{~min}$, the mixture was purified by column chromatography with a $\mathrm{DCM} / \mathrm{MeOH}$ gradient (100:0 to $\left.90: 10 ; \mathrm{R}_{\mathrm{f}}=0.2\right)$. The crude 6a.DBU salt was diluted in DCM $(10 \mathrm{~mL})$ and treated with $\mathrm{HCl} 6 \mathrm{~N}(3 * 10 \mathrm{~mL})$. The layers were separated and the organic layer was concentrated in vacuo to afford the chiral phosphoric acid $(R)-7 \mathbf{a}^{[11]}(35 \mathrm{mg}, 95 \%$ yield). $[\alpha]_{\mathrm{D}}=+931\left(c=1, \mathrm{CHCl}_{3}\right)$. The enantiomeric excess of the acids was measured by HPLC on an ID column.

\section{Phosphoric acid 7b (Ar = (5'-m-terphenyl)}

(a) Phosphites 5b,b' were obtained from $\mathbf{3} \mathbf{b}^{[11]}$ in $39 \%$ yield, as a $6: 4$ mixture of isomers $\left(R_{f}=0.7\right.$ in heptane/ EtOAc 7:3). ${ }^{31} \mathrm{P}$ NMR $\left(\mathrm{CDCl}_{3}\right): \delta 133$ and $131 \mathrm{ppm}$. HRMS (ESI) calcd. for $\mathrm{C}_{67} \mathrm{H}_{49} \mathrm{FeNO}_{3} \mathrm{P}[\mathrm{M}+\mathrm{H}]^{+}: 1002.2799$, found : 1002.2784 .

(b) Phosphates 6b, 6b' were separated on a CombiFlash $\AA$ system using a silica gel column. Eluents: toluene/heptane/THF gradient from $65: 35: 0$ to $65: 35: 1.5$ $\mathrm{R}_{\mathrm{f}}=0.41$ for $\mathbf{6 b}$ (major) and $0.38 /$ for $\mathbf{6 b}$ (toluene/heptane/THF $=6: 3.5: 1$ ).

6b: ${ }^{31} \mathrm{P}$ NMR $\left(\mathrm{CDCl}_{3}\right): \delta-15 \mathrm{ppm} .{ }^{1} \mathrm{H}$ NMR $(300 \mathrm{MHz}$, $\left.\mathrm{CDCl}_{3}\right): \delta 7.93(\mathrm{bs}, 1 \mathrm{H}), 7.8-7.6(\mathrm{~m}, 13 \mathrm{H}), 7.6-7.3(\mathrm{~m}$, $12 \mathrm{H}), 7.2-7.0(\mathrm{~m}, 8 \mathrm{H}), 6.39(\mathrm{~d}, J=8.5 \mathrm{~Hz}, 1 \mathrm{H}), 6.33(\mathrm{bs}$, $2 \mathrm{H}), 5.35(\mathrm{~m}, 1 \mathrm{H}), 4.63(\mathrm{~s}, 1 \mathrm{H}), 4.60(\mathrm{~s}, 1 \mathrm{H}), 4.54(\mathrm{~s}, 1 \mathrm{H})$ $4.51(\mathrm{~s}, 1 \mathrm{H}), 4.39{ }^{\prime}(\mathrm{s}, 2 \mathrm{H}), 4.36{ }^{\prime}(\mathrm{s}, 2 \mathrm{H}), 2.64^{\prime}(\mathrm{dd}, J=16.0$ 6.0 Hz, 1H), 2.53 (dd, $J=16.0,6.0 \mathrm{~Hz}, 1 \mathrm{H}) .{ }^{13} \mathrm{C} \mathrm{NMR}$ $\left(75.5 \mathrm{MHz}, \mathrm{CDCl}_{3}\right): \delta 147.0(\mathrm{~d}, J=6.9 \mathrm{~Hz}, \mathrm{C}), 145.9(\mathrm{~d}, J$ $=9.5 \mathrm{~Hz}, \mathrm{C}), 142.5$ (C), 142.1 (C), 141.4 (C), 140.7 (C), 138.3 (C), 138.1 (C), 136.3 (C), 133.5 (C), 132.1 (d, J= $6.5 \mathrm{~Hz}, \mathrm{C}), 131.5$ (C), 130.9 (C), $129.5(\mathrm{CH}), 129.3(\mathrm{CH})$ $129.0(\mathrm{CH}), 128.9(\mathrm{CH}), 128.1(\mathrm{CH}), 128.0(\mathrm{CH}), 127.7$ $(\mathrm{CH}), 127.5(\mathrm{CH}), 127.4(\mathrm{CH}), 127.2(\mathrm{CH}), 127.1(\mathrm{CH})$ $126.2(\mathrm{CH}), 126.1(\mathrm{CH}), 125.9(\mathrm{CH}), 122.5(\mathrm{CH}), 120.5$ (CH), $115.3(\mathrm{CN}), 85.9(\mathrm{C}), 85.8(\mathrm{C}), 76.8(\mathrm{CH}), 70.0$ $(\mathrm{CH}), 69.3(\mathrm{CH}), 67.0(\mathrm{CH}), 66.8(\mathrm{CH}), 65.7(\mathrm{CH}), 65.5$ $(\mathrm{CH}), 27.2\left(\mathrm{~d}, J_{(\mathrm{P}-\mathrm{C})}=7.2 \mathrm{~Hz}, \mathrm{CH}_{2}\right)$. IR : $v_{\mathrm{mx}}=3058,2955$, $2924,2854,1716,1684,1595,1512,1498,1455,1414$. $1302,1267,1231,1205,1183,1136,1078,1035,934,877$. HRMS (ESI) calcd. for $\mathrm{C}_{67} \mathrm{H}_{49} \mathrm{FeNO}_{4} \mathrm{P}[\mathrm{M}+\mathrm{H}]^{+}: 1018.2749$, found : 1018.2766. $[\alpha]_{\mathrm{D}}=+918\left(c=1, \mathrm{CHCl}_{3}\right)$.

6b': ${ }^{31} \mathrm{P}$ NMR $\left(\mathrm{CDCl}_{3}\right): \delta-15$ ppm. ${ }^{1} \mathrm{H}$ NMR $(300 \mathrm{MHz}$, $\left.\mathrm{CDCl}_{3}\right): \delta 8.08(\mathrm{bs}, 1 \mathrm{H}), 7.9-7.7(\mathrm{~m}, 13 \mathrm{H}), 7.7-7.4(\mathrm{~m}$ $12 \mathrm{H}), 7.3-7.2(\mathrm{~m}, 7 \mathrm{H}), 6.88(\mathrm{~d}, J=8.5 \mathrm{~Hz}, 1 \mathrm{H}), 6.46(\mathrm{~d}, J$ $=8.5 \mathrm{~Hz}, 1 \mathrm{H}), 6.42(\mathrm{~d}, J=8.5 \mathrm{~Hz}, 1 \mathrm{H}), 6.34(\mathrm{~d}, J=8.5 \mathrm{~Hz}$, $1 \mathrm{H}), 5.69(\mathrm{~m}, 1 \mathrm{H}), 4.73(\mathrm{~s}, 1 \mathrm{H}), 4.71(\mathrm{~s}, 1 \mathrm{H}), 4.61(\mathrm{~s}, 1 \mathrm{H})$, $4.59(\mathrm{~s}, 1 \mathrm{H}), 4.50(\mathrm{~s}, 2 \mathrm{H}), 4.48(\mathrm{~s}, 2 \mathrm{H}), 2.80(\mathrm{dd}, J=16.5$, $4.7 \mathrm{~Hz}, 1 \mathrm{H}), 2.52(\mathrm{dd}, J=16.5,8.4 \mathrm{~Hz}, 1 \mathrm{H}) .{ }^{3} \mathrm{C}$ NMR $(75$ $\left.\mathrm{MHz}, \mathrm{CDCl}_{3}\right): \delta 146.8(\mathrm{~d}, J=9.9 \mathrm{~Hz}, \mathrm{C}), 146.6(\mathrm{~d}, J=9.7$ 
$\mathrm{Hz}, \mathrm{C}), 142.6$ (C), 142.4 (C), 141.3 (C), 140.7 (C), 138.5 (C), $137.8(\mathrm{C}), 136.0(\mathrm{~d}, J=4.8 \mathrm{~Hz}, \mathrm{C}), 132.7(\mathrm{~d}, J=6.7$ $\mathrm{Hz}, \mathrm{C}), 132.4$ (d, $J=4.6 \mathrm{~Hz}, \mathrm{C}), 131.5(\mathrm{C}), 131.0(\mathrm{C})$, $129.8(\mathrm{CH}), 129.4(\mathrm{CH}), 129.1(\mathrm{CH}), 128.2(\mathrm{CH}), 127.8$ $(\mathrm{CH}), 127.7(\mathrm{CH}), 127.5(\mathrm{CH}), 127.1(\mathrm{CH}), 126.5(\mathrm{CH})$, $126.2(\mathrm{CH}), 126.1(\mathrm{CH}), 125.7(\mathrm{CH}), 122.3(\mathrm{CH}), 120.4$ $(\mathrm{CH}), 115.2(\mathrm{CN}), 85.7(\mathrm{C}), 85.6(\mathrm{C}), 76.2(\mathrm{~d}, J=4.9 \mathrm{~Hz}$ $\mathrm{CH}), 70.0(\mathrm{CH}), 69.4(\mathrm{CH}), 66.9(\mathrm{CH}), 66.7(\mathrm{CH}), 65.6$ $(\mathrm{CH}), 26.3\left(\mathrm{~d}, J=5.6 \mathrm{~Hz}, \mathrm{CH}_{2}\right)$. IR: $v_{\max }=3035,2926$, $2855,1595,1513,1456,1414,1297,1232,1206,1036$, 1009, 966, 937, 877.HRMS (ESI) calcd. for $\mathrm{C}_{67} \mathrm{H}_{49} \mathrm{FeNO}_{4} \mathrm{P}$ $[\mathrm{M}+\mathrm{H}]^{+}: 1018.2749$, found : 1018.2745. $[\alpha]_{\mathrm{D}}=-710(c=$ $1, \mathrm{CHCl}_{3}$ ).

(c) Phosphoric acid $(\boldsymbol{R})-7 \mathbf{b}$ was obtained in $67 \%$ yield $(53$ $\mathrm{mg}$ ) from $(R)-6 \mathbf{b}(81 \mathrm{mg})$. ${ }^{31} \mathrm{P}\left(\mathrm{DMSO}-d_{6}\right): \delta-12$. $[\alpha]_{\mathrm{D}}=$ $+775\left(c=1, \mathrm{CH}_{2} \mathrm{Cl}_{2}\right)$. HPLC: ID column, $\mathrm{THF} /$ Heptane/TFA/Et ${ }_{3} \mathrm{~N}$ 60:40:0.5:0.3).

Phosphoric acid 7c (Ar = p-biphenyl).

(a) Phosphites 5c,c' were obtained from $3 c^{[11]}$ in $44 \%$ yield, as a $1: 1$ mixture of isomers $\left(\mathrm{R}_{\mathrm{f}}=0.5\right.$ in heptane/ EtOAc 7:3). ${ }^{31} \mathrm{P}$ NMR $\left(\mathrm{CDCl}_{3}\right): \delta 132$ and $131 \mathrm{ppm}$. HRMS (ESI) calcd. for $\mathrm{C}_{55} \mathrm{H}_{40} \mathrm{FeNO}_{3} \mathrm{P}[\mathrm{M}+\mathrm{H}]^{+}: 850.2173$, found: 850.2178. The starting diol 3c has been prepared according to path (a) in Scheme 2 (see Supporting Information).

(b) Phosphates 6c, 6c' were separated on a CombiFlash ${ }^{\circledR}$ system using a silica gel column. Eluents: toluene/heptane/THF gradient from 60:30:0 to 60:30:2. $\mathrm{R}_{\mathrm{f}}$ $=0.39$ for $\mathbf{6 c}$ and 0.34 for $\mathbf{6 c}$ (toluene/heptane/THF $=$ 6:3:1). 6c: ${ }^{31} \mathrm{P}$ NMR $\left(\mathrm{CDCl}_{3}\right): \delta-15 \mathrm{ppm} .{ }^{1} \mathrm{H}$ NMR $(500$ $\left.\mathrm{MHz}, \mathrm{CDCl}_{3}\right): \delta 7.8-7.6(\mathrm{~m}, 8 \mathrm{H}), 7.6-7.3(\mathrm{~m}, 13 \mathrm{H}), 7.1(\mathrm{~m}$, $2 \mathrm{H}), 7.04$ (bs, 2H), 6.89 (d, $J=8.4 \mathrm{~Hz}, 1 \mathrm{H}), 6.34$ (d, $J=$ $8.4 \mathrm{~Hz}, 1 \mathrm{H}), 6.27$ (bs, 2H), $5.47(\mathrm{~m}, 1 \mathrm{H}), 4.66$ (bs, $2 \mathrm{H})$, 4.58 (bs, 1H), 4.54 (bs, 1H), 4.44 (bs, 2H), 4.42 (bs, 2H), $2.87(\mathrm{~d}, J=5.9 \mathrm{~Hz}, 2 \mathrm{H}) .{ }^{3} \mathrm{C}$ NMR $\left(75 \mathrm{MHz}^{3} \mathrm{CDCl}_{3}\right): \delta$ 147.0 (d, $J=7.3 \mathrm{~Hz}, \mathrm{C}), 146.2$ (d, $J=10.5 \mathrm{~Hz}, \mathrm{C}), 141.0$ (C), 140.9 (C), 140.7 (C), 140.6 (C), 136.6 (C), 136.3 (C), 136.2 (C), 133.4 (C), 131.9 (d, $J=7.9 \mathrm{~Hz}, \mathrm{C}), 132.0$ (C), 131.9 (C), $130.1(\mathrm{CH}), 129.7(\mathrm{CH}), 129.2(\mathrm{CH}), 129.0$ $(\mathrm{CH}), 128.9(\mathrm{CH}), 128.0(\mathrm{CH}), 127.9(\mathrm{CH}), 127.5(\mathrm{CH})$, $127.4(\mathrm{CH}), 126.2(\mathrm{CH}), 125.9(\mathrm{CH}), 122.3(\mathrm{CH}), 120.4$ $(\mathrm{CH}), 115.6(\mathrm{CN}), 86.5(\mathrm{C}), 86.4(\mathrm{C}), 76.7(\mathrm{C}), 70.1(\mathrm{CH})$, $69.5(\mathrm{CH}), 66.9(\mathrm{CH}), 66.7(\mathrm{CH}), 65.8(\mathrm{CH}), 65.7(\mathrm{CH})$, $27.6\left(\mathrm{~d}, J=7.3 \mathrm{~Hz}, \mathrm{CH}_{2}\right)$. IR: $v_{\max }=3032,2967,2926$, $2855,1601,1508,1488,1458,1399,1367,1304,1258$, 1212, 1185, 1128, 1055, 1034, 1022, 978, 934, 842, 768. HRMS (ESI) calcd. for $\mathrm{C}_{55} \mathrm{H}_{40} \mathrm{FeNO}_{4} \mathrm{P}[\mathrm{M}+\mathrm{H}]^{+}:$: 866.2123, found: 866.2188. $[\alpha]_{\mathrm{D}}=+1151\left(c=0.5, \mathrm{CHCl}_{3}\right)$.

6c': ${ }^{31} \mathrm{P}$ NMR $\left(\mathrm{CDCl}_{3}\right): \delta-15 \mathrm{ppm} .{ }^{1} \mathrm{H}$ NMR $(500 \mathrm{MHz}$, $\left.\mathrm{CDCl}_{3}\right): \delta 7.8-7.6(\mathrm{~m}, 9 \mathrm{H}), 7.6-7.3(\mathrm{~m}, 11 \mathrm{H}), 7.2(\mathrm{~m}, 2 \mathrm{H})$, 7.07 (bs, 2H), $6.68(\mathrm{~d}, J=8.0 \mathrm{~Hz}, 1 \mathrm{H}), 6.43(\mathrm{~d}, J=8.0 \mathrm{~Hz}$, $1 \mathrm{H}), 6.31$ (dd, $J=8.0,2.1 \mathrm{~Hz}, 1 \mathrm{H}), 6.27(\mathrm{dd}, J=8.0,2.1$ $\mathrm{Hz}, 1 \mathrm{H}), 5.56(\mathrm{~m}, 1 \mathrm{H}), 4.67(\mathrm{~s}, 2 \mathrm{H}), 4.55(\mathrm{~s}, 2 \mathrm{H}), 4.45(\mathrm{~s}$, $2 \mathrm{H}), 4.43(\mathrm{~s}, 2 \mathrm{H}), 2.70(\mathrm{dd}, J=16.5,4.8 \mathrm{~Hz}, 1 \mathrm{H}), 2.51(\mathrm{dd}$, $J=16.5,6.9 \mathrm{~Hz}, 1 \mathrm{H}){ }^{3} \mathrm{C} \mathrm{NMR}\left(75 \mathrm{MHz}, \mathrm{CDCl}_{3}\right): \delta$ 147.2 (d, $J=9.6 \mathrm{~Hz}, \mathrm{C}), 147.0(\mathrm{~d}, J=10.3 \mathrm{~Hz}, \mathrm{C}), 141.4$ (C), 141.3 (C), 141.2 (C), 140.9 (C), 136.9 (C), 136.3 (C), $133.2(\mathrm{~d}, J=6.9 \mathrm{~Hz}, \mathrm{C}), 132.7(\mathrm{~d}, J=6.0 \mathrm{~Hz}, \mathrm{C}), 131.7(\mathrm{C})$ $131.4(\mathrm{C}), 130.4(\mathrm{CH}), 130.2(\mathrm{CH}), 130.1(\mathrm{CH}), 129.7$ (CH), $129.5(\mathrm{CH}), 129.4(\mathrm{CH}), 128.4(\mathrm{CH}), 128.1(\mathrm{CH})$, $128.0(\mathrm{CH}), 127.8(\mathrm{CH}), 127.7(\mathrm{CH}), 126.8(\mathrm{CH}), 126.4$ $(\mathrm{CH}), 126.0(\mathrm{CH}), 122.6(\mathrm{CH}), 120.9(\mathrm{CH}), 116.0(\mathrm{CN})$, 86.5 (C), 86.4 (C), 76.8 (d, J= 5.5 Hz, CH), 70.5 (CH), $69.9(\mathrm{CH}), 67.2(\mathrm{CH}), 67.1(\mathrm{CH}), 66.1(\mathrm{CH}), 27.2(\mathrm{~d}, J=$ $\left.7.7 \mathrm{~Hz}, \mathrm{CH}_{2}\right) . \quad$ IR : $v_{\max }=3030,2925,2853,1730,1600$, $1508,1488,1457,1294,1254,1211,1184,1130,1034$, 1007, 971, 934, 840, 820. 'HRMS (ESI) calcd. for $\mathrm{C}_{55} \mathrm{H}_{40} \mathrm{FeNO}_{4} \mathrm{P}[\mathrm{M}+\mathrm{H}]^{+}:$: 866.2123, found: 866.2147. $[\alpha]_{\mathrm{D}}$ $-1138\left(c=0.5, \mathrm{CHCl}_{3}\right)$. An $S$-planar configuration has been assigned to compound $\mathbf{6} \mathbf{c}^{\mathbf{3}}$ by X-ray diffraction studies: CCDC 951975 contains the corresponding crystallographic data.

(c) Phosphoric acid $(\boldsymbol{R})-7 \mathrm{c}$ was obtained in $33 \%$ yield $(7$ $\mathrm{mg})$ from $(R)-6 \mathrm{c}(25 \mathrm{mg}) .{ }^{31} \mathrm{P}$ NMR (DMSO- $\left.d_{6}\right): \delta-12$ ppm. ${ }^{1} \mathrm{H}$ NMR $(600 \mathrm{MHz}$ DMSO-d $): 7.78(\mathrm{~d}, J=8.0 \mathrm{~Hz}$, $4 \mathrm{H}), 7.77(\mathrm{~d}, J=7.3 \mathrm{~Hz}, 4 \mathrm{H}), 7.69(\mathrm{~d}, J=8.0 \mathrm{~Hz}, 4 \mathrm{H})$, $7.51(\mathrm{t}, J=7.3 \mathrm{~Hz}, 4 \mathrm{H}), 7.40(\mathrm{t}, J=7.3 \mathrm{~Hz}, 2 \mathrm{H}), 7.09$ (bs,
$2 \mathrm{H}), 6.62(\mathrm{~d}, J=8.5 \mathrm{~Hz}, 2 \mathrm{H}), 6.50(\mathrm{~d}, J=8.5 \mathrm{~Hz}, 2 \mathrm{H})$, $4.86(\mathrm{~s}, 2 \mathrm{H}), 4.74(\mathrm{~s}, 2 \mathrm{H}), 4.45(\mathrm{~s}, 2 \mathrm{H}), 4.41(\mathrm{~s}, 2 \mathrm{H}) .{ }^{13} \mathrm{C}$ NMR $\left(150.7 \mathrm{MHz}\right.$, DMSO $\left.-d_{6}\right): \delta 146.8\left(\mathrm{~d}, J_{(\mathrm{P}-\mathrm{C})}=5.6 \mathrm{~Hz}\right.$, C), 139.9 (C), 138.7 (C), $137.0(\mathrm{C}), 131.6\left(\mathrm{~d}, J_{(\mathrm{P}-\mathrm{C})}=5.2\right.$ $\mathrm{Hz}, \mathrm{C}), 129.8(\mathrm{CH}), 129.5(\mathrm{C}), 129.0(\mathrm{CH}), 127.5(\mathrm{CH})$, $127.1(\mathrm{CH}), 126.7(\mathrm{CH}), 126.5(\mathrm{CH}), 126.0(\mathrm{CH}), 121.2$ $(\mathrm{CH}), 86.0(\mathrm{C}), 69.3(\mathrm{CH}), 68.7(\mathrm{CH}), 66.6(\mathrm{CH}), 65.5$ (CH). IR: $v_{\max }=3029,2923,2852,1600,1507,1488$, $1457,1398,1379,1259,1216,1190,1089,1017,1007$, 911, 838. HRMS (ESI) calcd. for $\mathrm{C}_{46} \mathrm{H}_{33} \mathrm{FeO}_{4} \mathrm{P}: 736.1466$, found : 736.1485. $[\alpha]_{\mathrm{D}}=+966\left(c=0.7, \mathrm{CHCl}_{3}\right)$.

Phosphoric acid 7d (Ar = 3,5-bis(trifluoromethyl)phenyl).

(a) Phosphites 5d,d' were obtained from $3 \mathbf{d}^{[11]}$ in $20 \%$ yield, as a 7:3 mixture of isomers $\left(R_{f}=0.7\right.$ in heptane/ EtOAc $7: 3) .{ }^{31} \mathrm{P}$ NMR $\left(\mathrm{CDCl}_{3}\right): \delta 136$ and $133 \mathrm{ppm}$ HRMS (ESI) calcd. for $\mathrm{C}_{47} \mathrm{H}_{28} \mathrm{~F}_{12} \mathrm{FeNO}_{3} \mathrm{P} \quad[\mathrm{M}+\mathrm{H}]^{+}$: 970.1043, found: 970.1098 . The starting diol 3d has been prepared according to path (b) in Scheme 2 (see Supporting Information).

(b) Phosphates 6d, 6d' were separated on a CombiFlash $\AA$ system using a silica gel column. Eluents: toluene/heptane/THF gradient from 70:30:0 to 70:30:1. $\mathrm{R}_{\mathrm{f}}$ $=0.38$ for $\mathbf{6 d}$ (major) and 0.34 for $\mathbf{6 d}$ (toluene/heptane/THF $=$ 7:3:1).

6d: ${ }^{31} \mathrm{P}$ NMR $\left(\mathrm{CDCl}_{3}\right): \delta-12$ ppm. ${ }^{19} \mathrm{~F} \mathrm{NMR}(282.4 \mathrm{MHz}$ $\left.\mathrm{CDCl}_{3}\right):-62.5$ and -62.6 . $\mathrm{H}$ NMR $\left(500 \mathrm{MHz}, \mathrm{CDCl}_{3}\right): \delta$ $8.02(\mathrm{~s}, 1 \mathrm{H}), 7.98(\mathrm{~s}, 3 \mathrm{H}), 7.96(\mathrm{~s}, 2 \mathrm{H}), 7.41(\mathrm{~m}, 3 \mathrm{H}), 7.24$ $(\mathrm{m}, 2 \mathrm{H}), 7.01(\mathrm{bs}, 2 \mathrm{H}), 6.94(\mathrm{~d}, J=8.7 \mathrm{~Hz}, 1 \mathrm{H}), 6.46(\mathrm{~d}, J$ $=8.7 \mathrm{~Hz}, 1 \mathrm{H}), 6.35(\mathrm{~d}, J=8.5 \mathrm{~Hz}, 1 \mathrm{H}), 6.23(\mathrm{~d}, J=8.53$ $\mathrm{Hz}, 1 \mathrm{H}), 5.56(\mathrm{q}, J=6.5 \mathrm{~Hz}, 1 \mathrm{H}), 4.67(\mathrm{~s}, 1 \mathrm{H}), 4.66(\mathrm{~s}$ $1 \mathrm{H}), 4.64(\mathrm{~s}, 1 \mathrm{H}), 4.57(\mathrm{~s}, 1 \mathrm{H}), 4.51(\mathrm{~s}, 2 \mathrm{H}), 4.47(\mathrm{~s}, 1 \mathrm{H})$ $2.96(\mathrm{~d}, J=6.0 \mathrm{~Hz}, 2 \mathrm{H}) .{ }^{13} \mathrm{C}$ NMR $\left(75.5 \mathrm{MHz}, \mathrm{CDCl}_{3}\right): \delta$ $146.6\left(\mathrm{~d}, J_{(\mathrm{P}-\mathrm{C})}=5.6 \mathrm{~Hz}, \mathrm{C}\right), 145.2\left(\mathrm{~d}, J_{(\mathrm{P}-\mathrm{C})}=8.7 \mathrm{~Hz}, \mathrm{C}\right)$ 139.4 (C), 138.8 (C), 136.1 (C), 136.0 (C), 132.3 (q, J J $=33.9 \mathrm{~Hz}, \mathrm{C}), 132.7(\mathrm{C}), 132.0\left(\mathrm{q}, J_{(\mathrm{F}-\mathrm{C})}=33.6 \mathrm{~Hz}, \mathrm{C}\right)$, $131.6(\mathrm{C}), 131.2(\mathrm{C}), 129.9(\mathrm{CH}), 129.3(\mathrm{CH}), 129.2(\mathrm{CH})$, $127.5(\mathrm{CH}), 127.3(\mathrm{CH}), 127.2(\mathrm{CH}), 127.0(\mathrm{CH}), 125.7$ $(\mathrm{CH}), 123.6\left(\mathrm{q}, J_{(\mathrm{F}-\mathrm{C})}=273.0 \mathrm{~Hz}, \mathrm{CF}_{3}\right), 123.5\left(\mathrm{q}, J_{(\mathrm{F}-\mathrm{C})}=\right.$ $\left.273.0 \mathrm{~Hz}, \mathrm{CF}_{3}\right), 123.3(\mathrm{CH}), 121.8(\mathrm{CH}), 120.0(\mathrm{CH})$ $115.1(\mathrm{CN}), 85.3(\mathrm{C}), 85.2(\mathrm{C}), 77.0\left(\mathrm{~d}, J_{(\mathrm{P}-\mathrm{C})}=3.9 \mathrm{~Hz}, \mathrm{C}\right)$, $70.4(\mathrm{CH}), 69.7(\mathrm{CH}), 67.4(\mathrm{CH}), 67.1(\mathrm{CH}), 65.7(\mathrm{CH})$ $65.5(\mathrm{CH}), 27.5\left(\mathrm{~d}, J_{(\mathrm{P}-\mathrm{C})}=7.7 \mathrm{~Hz}, \mathrm{CH}_{2}\right)$. IR : $v_{\max }=3089$ $2929,1723,1621,1604,1514,1457,1414,1373,1277$ $1179,1130,1052,1037,1016,931,900$. HRMS (ESI) calcd. for $\mathrm{C}_{47} \mathrm{H}_{28} \mathrm{~F}_{12} \mathrm{FeNO}_{4} \mathrm{P}[\mathrm{M}+\mathrm{H}]^{+}$: 986.0992, found : 986.1035. $[\alpha]_{\mathrm{D}}=+722\left(c=1, \mathrm{CHCl}_{3}\right)$.

6d': ${ }^{31} \mathrm{P}$ NMR $\left(\mathrm{CDCl}_{3}\right): \delta-12.2 \mathrm{ppm} .{ }^{19} \mathrm{~F}$ NMR $(282.4$ $\left.\mathrm{MHz}, \mathrm{CDCl}_{3}\right)$ : -62.57 and $-62.53 \mathrm{ppm} .{ }^{1} \mathrm{H}$ NMR $(300$ $\left.\mathrm{MHz}, \mathrm{CDCl}_{3}\right): \delta 8.01(\mathrm{~s}, 2 \mathrm{H}), 7.98(\mathrm{~s}, 1 \mathrm{H}), 7.88(\mathrm{~s}, 1 \mathrm{H})$, $7.80(\mathrm{~s}, 2 \mathrm{H}), 7.43-7.38(\mathrm{~m}, 3 \mathrm{H}), 7.35-7.30(\mathrm{~m}, 2 \mathrm{H}), 7.02(\mathrm{~s}$ $1 \mathrm{H}), 6.96(\mathrm{~s}, 1 \mathrm{H}), 6.86(\mathrm{~d}, J=8.7 \mathrm{~Hz}, 1 \mathrm{H}), 6.43$ (d, $J=8.7$ $\mathrm{Hz}, 1 \mathrm{H}), 6.29$ (d, $J=8.8 \mathrm{~Hz}, 1 \mathrm{H}), 6.21$ (d, $J=8.8 \mathrm{~Hz}, 1 \mathrm{H})$, $5.67(\mathrm{q}, J=6.6 \mathrm{~Hz}, 1 \mathrm{H}), 4.65(\mathrm{~s}, 1 \mathrm{H}), 4.61(\mathrm{~s}, 2 \mathrm{H}), 4.52(\mathrm{~s}$, $1 \mathrm{H}), 4.47(\mathrm{~s}, 2 \mathrm{H}), 4.44(\mathrm{~s}, 2 \mathrm{H}), 2.94(\mathrm{dd}, J=16.7,6.2 \mathrm{~Hz}$ $1 \mathrm{H}), 2.84$ (dd, $J=16.7,6.2 \mathrm{~Hz}, 1 \mathrm{H}) .{ }^{13} \mathrm{C}$ NMR $(75.5 \mathrm{MHz}$, $\left.\mathrm{CDCl}_{3}\right): \delta 146.6\left(\mathrm{~d}, J_{(\mathrm{P}-\mathrm{C})}=5.6 \mathrm{~Hz}, \mathrm{C}\right), 145.4\left(\mathrm{~d}, J_{(\mathrm{P}-\mathrm{C})}=8.7\right.$ $\mathrm{Hz}, \mathrm{C}), 139.3$ (C), 138.8 (C), 136.1 (C), 136.0 (C), 132.7 (C), $132.3\left(\mathrm{q}, J_{(\mathrm{F}-\mathrm{C})}=33.3 \mathrm{~Hz}, \mathrm{C}\right), 132.0\left(\mathrm{q}, J_{(\mathrm{F}-\mathrm{C})}=33.3 \mathrm{~Hz}\right.$, C), 131.7 (C), $131.2(\mathrm{C}), 131.1(\mathrm{C}), 130.1(\mathrm{CH}), 129.4$ $(\mathrm{CH}), 129.3(\mathrm{CH}), 129.2(\mathrm{CH}), 129.1(\mathrm{CH}), 127.7(\mathrm{CH})$, $127.2(\mathrm{CH}), 127.0(\mathrm{CH}), 126.1(\mathrm{CH}), 125.3(\mathrm{C}), 123.1$ $(\mathrm{CH}), 121.8(\mathrm{CH}), 121.7(\mathrm{CH}), 120.2(\mathrm{CH}), 115.1(\mathrm{CN})$ $85.3(\mathrm{C}), 85.2(\mathrm{C}), 76.7\left(\mathrm{~d}, J_{(\mathrm{P}-\mathrm{C})}=3.3 \mathrm{~Hz}, \mathrm{C}\right), 70.5(\mathrm{CH})$, $70.4(\mathrm{CH}), 69.8(\mathrm{CH}), 67.3(\mathrm{CH}), 67.1(\mathrm{CH}), 65.7(\mathrm{CH})$, $65.6(\mathrm{CH}), 27.0\left(\mathrm{~d}, J_{(\mathrm{P}-\mathrm{C})}=6.3 \mathrm{~Hz}, \mathrm{CH}_{2}\right) . \mathrm{IR}: v_{\max }=3089$ $2931,1719,1620,1604,1514,1457,1413,1373,1277$ $1180,1130,1051,1037,1015,934,900 .[\alpha]_{\mathrm{D}}=-737(c=$ $\left.1, \mathrm{CHCl}_{3}\right)$.

General procedure for the synthesis of the Hantzsch esters 9d-f. ${ }^{[27]}$ Paraformaldehyde (1 eq.), ammonium acetate $(2$ eq. $)$ and the desired acetoacetate $\mathrm{MeCOCH}_{2} \mathrm{CO}_{2} \mathrm{R}$ (2 eq.) were refluxed under argon for $2 \mathrm{~h}$ under strong agitation. After cooling, the product was recrystallized from ethanol. 9d is a known product. ${ }^{[27]}$

Bis-(4-methoxybenzyl) 2,6-dimethyl-1,4-dihydropyridine-3,5-dicarboxylate, 9e: ${ }^{1} \mathrm{H}$ NMR (500 MHz, DMSO- 
$\left.d_{6}\right): \delta 8.37(\mathrm{bs}, 1 \mathrm{H}), 7.27(\mathrm{~d}, J=8.5 \mathrm{~Hz}, 4 \mathrm{H}), 6.90(\mathrm{~d}, J=$ $8.5 \mathrm{~Hz}, 4 \mathrm{H}), 5.01(\mathrm{~s}, 4 \mathrm{H}), 3.75(\mathrm{~s}, 6 \mathrm{H}), 3.16(\mathrm{~s}, 2 \mathrm{H}), 2.11(\mathrm{~s}$, $6 \mathrm{H})$.

Bis-(4-benzyloxybenzyl) 2,6-dimethyl-1,4-dihydropyridine-3,5-dicarboxylate, 9f: ${ }^{1} \mathrm{H}$ NMR $(300 \mathrm{MHz}$, DMSO$\left.d_{6}\right): \delta 8.38(\mathrm{bs}, 1 \mathrm{H}), 7.44-7.29(\mathrm{~m}, 14 \mathrm{H}), 6.98(\mathrm{~d}, J=8.4 \mathrm{~Hz}$, $4 \mathrm{H}), 5.09(\mathrm{~s}, 4 \mathrm{H}), 5.01(\mathrm{~s}, 4 \mathrm{H}), 3.75(\mathrm{~s}, 6 \mathrm{H}), 3.16(\mathrm{~s}, 2 \mathrm{H})$, $2.11(\mathrm{~s}, 6 \mathrm{H}) ;{ }^{13} \mathrm{C}$ NMR $\left(75 \mathrm{MHz}, \mathrm{DMSO}-d_{6}\right): \delta 166.9(\mathrm{CO})$, 158.0 (C), 147.0 (C), 137.0 (C), 129.4 (CH), 129.1 (C), $128.4(\mathrm{CH}), 127.8(\mathrm{CH}), 127.6(\mathrm{CH}) 114.6(\mathrm{CH}), 96.9(\mathrm{C})$, $69.2\left(\mathrm{CH}_{2}\right), 64.4\left(\mathrm{CH}_{2}\right), 24.7\left(\mathrm{CH}_{2}\right), 18.0\left(\mathrm{CH}_{3}\right)$. HRMS (ESI) calcd. for $\mathrm{C}_{37} \mathrm{H}_{36} \mathrm{NO}_{6}[\mathrm{M}+\mathrm{H}]^{+}: 590.2543$, found: 590.2524.

Representative procedure for the catalytic reductions of $\alpha$-arylquinolines.

A solution of 2-phenylquinoline 10a $(11 \mathrm{mg}, 0.05 \mathrm{mmol})$, Hantzsch dihydropyridine 9a $(0.12 \mathrm{mmol})$ and the acid catalyst $7 \mathbf{a}(0.005 \mathrm{mmol})$ in toluene $(1 \mathrm{ml})$ was stirred at r.t. for $2 \mathrm{~h}$. The solvent was removed under reduced pressure and the residue was purified on silica gel with toluene as the eluent. 2-Phenyl-1,2,3,4-tetrahydroquinoline 11a was obtained as a colorless oil. E.e.s were determined by HPLC using a CHIRALPAK® IB column. Eluent: $i-\mathrm{PrOH} / n-$ heptane 5:95, at a flow rate of $1 \mathrm{~mL} / \mathrm{min}$ [detection at 275 $\mathrm{nm}$ ]. Retention times; $6.7 \mathrm{~min}$ for $(-)-(S)-11 a$ and $8.2 \mathrm{~min}$ $(+)-(R)-11 \mathrm{a}$. $\left[\mathrm{Litt}^{[23]}(S)-11 \mathrm{a}:[\alpha]_{\mathrm{D}}=-35.7(\mathrm{c}=0.8\right.$, $\left.\mathrm{CHCl}_{3}\right)$.

2-(4-methoxyphenyl)-1,2,3,4-tetrahydroquinoline 11b: CHIRALPAK $®$ IB. Eluent: $i-P r O H / n$-heptane, 5:95 at a flow rate of $1 \mathrm{~mL} / \mathrm{min}$ [detection at $250 \mathrm{~nm}$ ]. Retention times: $7.7 \mathrm{~min}[(-)-(S)-\mathbf{1 1 b}]$ and $17.9 \mathrm{~min}[(+)-(R)-\mathbf{- 1 1 b}]$. [Litt: ${ }^{[23]}(S)-11 b:[\alpha]_{\mathrm{D}}=-26.1\left(\mathrm{c}=1, \mathrm{CHCl}_{3}\right), 86 \%$ ee].

2-(2-naphthyl)-1,2,3,4-tetrahydroquinoline 11c: CHIRALPAK ${ }^{\circ}$ IB. Eluent: $i-\mathrm{PrOH} / n$-heptane, 5:95 at a flow rate of $1 \mathrm{~mL} / \mathrm{min}$ [detection at $250 \mathrm{~nm}$ ]. Retention times: $9.6 \mathrm{~min}[(-)-(S)-\mathbf{1 1 c}]$ and $15.5 \mathrm{~min}[(+)-(R)-11 \mathrm{c}]$. [Litt: ${ }^{[23]}(S)-11 \mathrm{c}:[\alpha]_{\mathrm{D}}=-27.5\left(\mathrm{c}=1, \mathrm{CHCl}_{3}\right), 91 \%$ ee].

2-(p-biphenyl)-1,2,3,4-tetrahydroquinoline 11d: CHIRALPAK ${ }^{\circledR}$ IB. Eluent: $i$ - $P r O H / n$-heptane, 5:95 at a flow rate of $1 \mathrm{~mL} / \mathrm{min}$ [detection at $250 \mathrm{~nm}$ ]. Retention times: 9.4 min $[(-)-(S)-11 d]$ and $17.9 \min [(+)-(R)-11 d]$. [Litt: ${ }^{[21 a]}(S)-11 d:[\alpha]_{\mathrm{D}}=-13.8\left(\mathrm{c}=1, \mathrm{CHCl}_{3}\right),>99 \%$ ee].

2-(3,5-bis(trifluoromethyl)phenyl)-1,2,3,4-tetrahydroquinoline 11e: CHIRALPAK ${ }^{\circledR}$ IB. Eluent: $i-\mathrm{PrOH} / n$ heptane, $5: 95$ at a flow rate of $1 \mathrm{~mL} / \mathrm{min}$ [detection at 250 $\mathrm{nm}]$. Retention times: $8.4 \mathrm{~min}[(-)-11 e]$ and $17.2 \mathrm{~min}[(+)-$ 11e].

2-(1-naphthyl)-1,2,3,4-tetrahydroquinoline

11f:

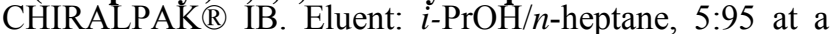
flow rate of $1 \mathrm{~mL} / \mathrm{min}$ [detection at $250 \mathrm{~nm}$ ]. Retention times: 10.7 min $[(-)-(S)-\mathbf{1 1 f}]$ and $18.1 \mathrm{~min}[(+)-(R)-\mathbf{1 1 f}]$. [Litt: ${ }^{[28]}(R)-11 \mathrm{c}:[\alpha]_{\mathrm{D}}=+117\left(\mathrm{c}=1, \mathrm{CHCl}_{3}\right), 88 \%$ ee].

2-(1-cyclohexyl)-1,2,3,4-tetrahydroquinoline 11g: ${ }^{\text {[21b] }}$

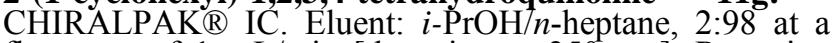
flow rate of $1 \mathrm{~mL} / \mathrm{min}$ [detection at $250 \mathrm{~nm}$ ]. Retention times: 4.4 min $[(+)-(S)-11 g]$ and 4.7 min $[(-)-(R)-11 g]$. [Litt: ${ }^{[29]}(S)-11 g:[\alpha]_{\mathrm{D}}=+48.3\left(\mathrm{c}=0.1, \mathrm{CHCl}_{3}\right), 96 \%$ ee].

\section{Acknowledgements}

This work was supported by the Paris-Sud University, the ICSN, the Agence Nationale de la Recherche (ANR Blanc SIMI7 2011, project "Chiracid") and the COST ORCA action CM0905.

\section{References}

1] D. Uraguchi, M. Terada, J. Am. Chem. Soc. 2004, 126, 5356-5357.

[2] T. Akiyama, J. Itoh, K. Yokota, K. Fuchibe, Angew. Chem. Int. Ed. 2004, 43, 1566-1568.
[3] a) M. Terada, Synthesis 2010, 1929-1982; b) S. Schenker, A. Zamfir, M. Freund, S. B. Tsogoeva, Eur. J. Org. Chem. 2011, 2209-2222; c) J. Yu, F. Shi, L.-Z. Gong, Acc. Chem. Res. 2011, 44, 1156-1171; d) M. Rueping, A. Kuenkel, I. Atodiresei, Chem. Soc. Rev. 2011, 40, 4539-4549; e) J. Lv, S. Luo, Chem. Commun. 2013, 49, 847-858.

[4] K. Mori, Y. Ichikawa, M. Kobayashi, Y. Shibata, M. Yamanaka, T. Akiyama, J. Am. Chem. Soc. 2013, 135, 3964-3970.

[5] T. Honjo, R. J. Phipps, V. Rauniyar, F. D. Toste, Angew. Chem. Int. Ed. 2012, 51, 9684-9688.

[6] a) J.-W. Lee, B. List, J. Am. Chem. Soc. 2012, 134, 18245-18248; b) J. Guin, G. Varseev, B. List, J. Am. Chem. Soc. 2013, 135, 2100-2103.

[7] a) X. Li, Y. Zhao, H. Qu, Z. Mao, X. Lin, Chem. Commun. 2013, 49, 1401-1403; b) D. Huang, F. Xu, T. Chen, Y. Wang, X. Lin, RSC Adv. 2013, 3, 573-578.

[8] a) I. Čorić, S. Müller, B. List, J. Am. Chem. Soc. 2010, 132, 17370-17373; b) F. Xu, D. Huang, C. Han, W. Shen, X. Lin, Y. Wang, J. Org. Chem. 2010, 75, 86778680 ; c) C.-H. Xing, Y.-X. Liao, J. Ng, Q.-S. Hu, J. Org. Chem. 2011, 76, 4125-4131; d) S. Müller, M. J. Webber, B. List, J. Am. Chem. Soc. 2011, 133, 1853418537; e) F. Xu, D. Huang, X. Lin, Y. Wang, Org. Biomol. Chem. 2012, 10, 4467-4470.

[9] a) G. B. Rowland, H. Zhang, E. B. Rowland, S. Chennamadhavuni, Y. Wang, J. C. Antilla, J. Am. Chem. Soc. 2005, 127, 15696-15697; b) E. B. Rowland, G. B. Rowland, E. Rivera-Otero, J. C. Antilla, J. Am. Chem. Soc. 2007, 129, 12084-12085; c) G. Li, Y. Liang, J. C. Antilla, J. Am. Chem. Soc. 2007, 129, 5830-5831; d) G. Della Sala, A. Lattanzi, Org. Lett. 2009, 11, 3330-3333; e) S. E. Larson, J. C. Baso, G. Li, J. C. Antilla, Org. Lett. 2009, 11, 5186-5189

[10] Selected examples. DMAP analogues: a) J. C. Ruble, H. A. Latham, G. C. Fu, J. Am. Chem. Soc. 1997, 119, 1492-1493; b) S. Y. Lee, J. M. Murphy, A. Ukai, G. C. Fu, J. Am. Chem. Soc. 2012, 134, 15149-15153. Phanephos: c) P. J. Pye, K. Rossen, R. A. Reamer, N. N. Tsou, R. P. Volante, P. J. Reider, J. Am. Chem. Soc. 1997, 119, 6207-6208. Paracyclophane based NHCs: d) Y. Ma, C. Song, C. Ma, Z. Sun, Q. Chai, M. B. Andrus, Angew. Chem. Int. Ed. 2003, 42, 5871-5874. Josiphos and analogous ferrocenic phosphines: e) A. Togni, C. Breutel, A. Schnyder, F. Spindler, H. Landert, A. Tijani, J. Am. Chem. Soc. 1994, 116, 4062-4066; f) T. J. Colacot, Chem. Rev. 2003, 103, 3101-3118. Others: g) A. Zanotti-Gerosa, C. Malan, D. Herzberg, Org. Lett. 2001, 3, 3687-3690; h) S. E. Gibson, J. D. Knight, Org. Biomol. Chem. 2003, 1, 1256-1269.

[11] J. Stemper, K. Isaac, V. Duret, P. Retailleau, A. Voituriez, J.-F. Betzer, A. Marinetti, Chem. Commun. 2013, 49, 6084-6086.

[12] D. Enders, M. Ludwig, G. Raabe, Chirality 2012, 24, 215-222.

[13] a) E. E. Nifant'ev, E. N. Rasadkina, Y. B. Evdokimenkova, Russ. J. Gen. Chem. 2001, 71, 366- 
372; b) E. E. Nifant'ev, E. N. Rasadkina, P. V. Slitikov, L. K. Vasyanina, Phosphorus, Sulfur and Silicon 2005, 180, 513-526; c) E. N. Rasadkina, A. V. Petrov, E. E. Nifant'ev, Russ. J. Gen. Chem. 2007, 77, 241-247.

[14] M. Herberhold, A. Hofmann, W. Milius, J. Organomet. Chem. 1998, 555, 187-200.

[15] a) A. G. Osborne, R. H. Whiteley, R. E. Meads, J. Organomet. Chem. 1980, 193, 345-357; b) D. Seyferth, H. P. Withers, Organometallics 1982, 1, 1275-1282; c) C. H. Honeyman, D. A. Foucher, F. Y. Dahmen, R. Rulkens, A. J. Lough, I. Manners, Organometallics 1995, 14, 5503-5512; d) H. Brunner, J. Klankermayer, M. Zabel, J. Organomet. Chem. 2000, 601, 211-219; e) R. Resendes, J. M. Nelson, A. Fischer, F. Jäkle, A. Bartole, A. J. Lough, I. Manners, J. Am. Chem. Soc. 2001, 123, 2116-2126; f) Y. Tanimoto, Y. Ishizu, K. Kubo, K. Miyoshi, T. Mizuta, J. Organomet. Chem. 2012, 713, 80-88.

[16] S. Grimme, Chem. Eur. J. 2004, 10, 3423-3429.

[17] S. M. Bachrach, J. Phys. Chem. A 2011, 115, 23962401.

[18] a) W. Bannwarth, A. Trzeciak, Helv. Chim. Acta 1987, 70, 175-186; b) Q.-M. Gu, G. D. Prestwich, J. Org. Chem. 1996, 61, 8642-8647; c) K. Seio, T. Wada, K. Sakamoto, S. Yokoyama, M. Sekine, J. Org. Chem. 1996, 61, 1500-1504; d) G. Jiang, Y. Xu, G. D. Prestwich, J. Org. Chem. 2006, 71, 934-939.

[19] a) J.-H. Zhang, J. Liao, X. Cui, K.-B. Yu, J. Zhu, J.-G. Deng, S.-F. Zhu, L.-X. Wang, Q.-L. Zhou, L. W. Chung, T. Ye, Tetrahedron: Asymmetry 2002, 13, 1363-1366; b) J. Bao, W. D. Wulff, J. B. Dominy, M. J. Fumo, E. B. Grant, A. C. Rob, M. C. Whitcomb, S.-M. Yeung, R. L. Ostrander, A. L. Rheingold, J. Am. Chem. Soc. 1996, 118, 3392-3405; c) Z. Ding, W. E. G. Osminski, H. Ren, W. D. Wulff, Org. Process Res. Dev. 2011, 15, 1089-1107.

[20] P. Kumar, R. K. Upadhyay, R. K. Pandey, Tetrahedron: Asymmetry 2004, 15, 3955-3959.

[21] a) M. Rueping, A. P. Antonchick, T. Theissmann, Angew. Chem. Int. Ed. 2006, 45, 3683-3686; b) Q.-S. Guo, D.-M. Du, J. Xu, Angew. Chem. Int. Ed. 2008, 47, 759-762; c) D. S. Kundu, J. Schmidt, C. Bleschke, A. Thomas, S. Blechert, Angew. Chem. Int. Ed. 2012, 57, 5456-5459; d) M. Rueping, E. Sugiono, C. Azap, T. Theissmann, M. Bolte, Org. Lett. 2005, 7, 3781-3783; e) S. Hoffmann, A. M. Seayad, B. List, Angew. Chem. Int. Ed. 2005, 44, 7424-7427; f) M. Rueping, A. P. Antonchick, Angew. Chem. Int. Ed. 2007, 46, 45624565; g) M. Rueping, E. Sugiono, F. R. Schoepke, Synlett 2010, 852-865; h) C. Zheng, S.-L. You, Chem. Soc. Rev. 2012, 41, 2498-2518.

[22] a) X. Cheng, S. Vellalath, R. Goddard, B. List, J. Am. Chem. Soc. 2008, 130, 15786-15787; b) N. Li, X.-H. Chen, J. Song, S.-W. Luo, W. Fan, L.-Z. Gong, J. Am. Chem. Soc. 2009, 131, 15301-15310; c) Q. Gu, Z.-Q. Rong, C. Zheng, S.-L. You, J. Am. Chem. Soc. 2010, 132, 4056-4057; d) Y. Xie, Y. Zhao, B. Qian, L. Yang, C. Xia, H. Huang, Angew. Chem. Int. Ed. 2011, 50,
5682-5686; e) G. Dagousset, P. Retailleau, G. Masson, J. Zhu, Chem. Eur. J. 2012, 18, 5869-5873; f) L. Caruana, M. Fochi, S. Ranieri, A. Mazzanti, L. Bernardi, Chem. Commun. 2013, 49, 880-882.

[23] Q.-A. Chen, K. Gao, Y. Dun, Z.-S. Ye, L. Shi, Y. Yang, Y.-G. Zhou, J. Am. Chem. Soc. 2012, 134, 24422448.

[24] Acid 7e has been prepared by method (b) (Scheme 2, see supporting information)

[25] a) L. Simón, J. M. Goodman, J. Am. Chem. Soc. 2008, 130, 8741-8747; b) T. Marcelli, P. Hammar, F. Himo, Chem. Eur. J. 2008, 14, 8562-8571.

[26] a) Q. Kang, Z.-A. Zhao, S.-L. You, Adv. Synth. Catal. 2007, 349, 1657-1660; b) M. Rueping, T. Theissmann, S. Raja, J. W. Bats, Adv. Synth. Catal. 2008, 350, 10011006; c) M. Rueping, F. Tato, F. R. Schoepke, Chem. Eur. J. 2010, 16, 2688-2691; d) T. B. Nguyen, H. Bousserouel, Q. Wang, F. Guéritte, Org. Lett. 2010, 12, 4705-4707; e)T. B. Nguyen, H. Bousserouel, Q. Wang, F. Guéritte, Adv. Synth. Catal. 2011, 353, 257-262.

[27] M. W. Roomi, J. Med. Chem. 1975, 18, 457-460.

[28] T. Wang, L.-G. Zhuo, Z. Li, F. Chen, Z. Ding, Y. He, Q.-H. Fan, J. Xiang, Z.-X. Yu, A. S. C. Chan, J. Am. Chem. Soc. 2011, 133, 9878-9891.

[29] W. Tang, Y. Sun, L. Xu, T. Wang, Q. Fan, K.-H. Lam, A. S. C. Chan, Org. Biomol. Chem. 2010, 8, 3464-3471.

[30] M. J. Frisch, G. W. Trucks, H. B. Schlegel, G. E. Scuseria, M. A. Robb, J. R. Cheeseman, G. Scalmani, Barone, V., B. Mennucci, G. A. Petersson, H. Nakatsuji, M. Caricato, X. Li, H. P. Hratchian, A. F. Izmaylov, J. Bloino, G. Zheng, J. L. Sonnenberg, M. Hada, M. Ehara, K. Toyota, R. Fukuda, J. Hasegawa, M. Ishida, T. Nakajima, Y. Honda, O. Kitao, H. Nakai, T. Vreven, J. A. J. Montgomery, J. E. Peralta, F. Ogliaro, M. Bearpark, J. J. Heyd, E. Brothers, K. N. Kudin, V. N. Staroverov, T. Keith, R. Kobayashi, J. Normand, K. Raghavachari, A. Rendell, J. C. Burant, S. S. Iyengar, J. Tomasi, M. Cossi, N. Rega, J. M. Millam, M. Klene, J. E. Knox, J. B. Cross, V. Bakken, C. Adamo, J. Jaramillo, R. Gomperts, R. E. Stratmann, O. Yazyev, A. J. Austin, R. Cammi, C. Pomelli, J. W. Ochterski, R. L. Martin, K. Morokuma, V. G. Zakrzewski, G. A. Voth, P. Salvador, J. J. Dannenberg, S. Dapprich, A. D. Daniels, O. Farkas, J. B. Foresman, J. V. Ortiz, J. Cioslowski, D. J. Fox, 2010, Gaussian 09, revision B.01, 2010, Gaussian, Inc, Wallingford, CT.

[31] Y. Zhao, D. G. Truhlar, Theor. Chem. Account 2008, 120, 215-241.

[32] N. M. Ali, A. McKillop, M. B. Mitchell, R. A. Rebelo, P. J. Wallbank, Tetrahedron: 1992, 48, 8117-8126.

[33] N. T. Patil, V. S. Raut, J. Org. Chem. 2010, 75, 69616964.

[34] A. Kamal, G. B. R. Khanna, R. Ramu, Tetrahedron: 2002, 13, 2039-2051 
